\title{
Review
}

\section{Proximate mechanisms of age polyethism in the honey bee, Apis mellifera L.}

\author{
Nicholas W. Calderone* \\ Department of Entomology, Comstock Hall, Cornell University, Ithaca, NY 14853, USA
}

(Received 12 September 1997; accepted 4 December 1997)

\begin{abstract}
Workers in most insect societies exhibit a division of labor known as age polyethism, so named because workers tend to perform different tasks at different times in their lives. The most common explanation for this phenomenon involves a weak causal link between a worker's age and its occupation. However, available estimates of age effects are generally confounded with other sources of variability. Further, there is considerable variation in the age at which each task is performed. Consequently, the role of age in division of labor remains unresolved. An alternative model, christened 'foraging-for-work', explains age polyethism without a causal link between age and occupation. The specific algorithm, however, is too restrictive to apply in many task situations, and it is inconsistent with existing data on how workers actually locate and select tasks in certain contexts. Therefore, it cannot serve as a general model for task location/selection or for age polyethism. The model's conceptual basis, however, that an age-neutral mechanism can generate age polyethism, is an important contribution that demands further study. The current dialogue over proximate mechanisms of age polyethism has helped to clarify the pattern of behavioral ontogeny in honey bees. A conservative interpretation of existing data is that behavioral ontogeny is characterized by a nest phase followed by a foraging phase. The timing of the transition between these phases is determined more by the environment and physiological processes than by age. Whether nest tasks also follow a necessary sequence is less certain and requires further study. (.) Inra/DIB/AGIB/Elsevier, Paris
\end{abstract}

Apis mellifera / social behavior / age polyethism / self-organization / division of labor / emergent property / social insects

\section{INTRODUCTION}

The enormous success of the social insects (Wilson, 1985, 1987) is generally attributed to one of their cardinal characteristics - division of labor. Female nestmates exhibit varying degrees of reproductive division of labor (Wilson, 1971;

\footnotetext{
* Correspondence and reprints

Tel.: (1) 607254 7417; fax: (1) 607255 0939; e-mail: nwc4@cornell.edu
} 
Michener, 1974; Ross and Matthews, 1991). This division is most complete in species with distinct queen and worker castes, such as the ants, honey bees and termites. In those species, the queen lays most of the eggs, while the workers engage in a variety of tasks necessary for the growth and maintenance of the colony. The distribution of workers among tasks is dynamic, changing in response to available resources and the colony's state, both of which are constantly in a state of flux. The apparent coordination among the members of a colony's workforce is one of the most fascinating phenomena in the animal kingdom. It is also one of the most puzzling, especially in the more populous societies where one typically finds thousands or even millions of workers performing tasks in a highly efficient and organized manner (Wilson, 1971; Michener, 1974; Hölldobler and Wilson, 1990) despite the absence of a 'management caste' characteristic of most human enterprises.

Despite the lack of a hierarchically determined task structure, the distribution of workers among tasks is not random. A division of labor exists, reflecting a variety of factors, including worker size, physical caste and previous experience (Lenoir, 1987). The most commonly observed pattern of division of labor is known as age polyethism (Wilson, 1971; Michener, 1974; Oster and Wilson, 1978; Hölldobler and Wilson, 1990), so named because workers tend to perform different tasks at different times in their lives. Typically, a worker begins its adult life in a centrally located task zone, the brood area, where it performs tasks related to brood rearing. As it ages, it moves to areas of the nest used for other purposes, and its behavioral repertoire changes accordingly. Eventually, it undertakes foraging activities outside the nest and, thereafter, does not generally engage in nest activities. Variability in individual patterns of age polyethism is a well-documented feature of this system of division of labor. A stylized representation of age polyethism in one species, the honey bee, Apis mellifera, is presented in figure l (after Seeley, 1982).

Traditionally, age polyethism has been assumed to be the result of a weak causal link between a worker's age and its occupation. Recently, considerable attention has been given to a completely age-neutral mechanism as a plausible alternative to this traditional model. My purposes here are to: 1) review the development of the concept of age polyethism in one species, the honey bee, A. mellifera; 2) present a critical analysis of the two principal proximate models of age polyethism; and 3) offer an alternative framework of age polyethism based on a more conservative interpretation of the existing data on behavioral ontogeny. I use the term 'age polyethism' throughout strictly as a phenomenological description of worker behavior, not to imply a causal relationship between age and behavior. I use the term 'age-based' to imply a causal relation between age and behavior.

\section{A HISTORICAL PERSPECTIVE OF AGE POLYETHISM IN THE HONEY BEE}

Age polyethism is a somewhat inappropriate designation for the phenomenon it describes. While age has historically been seen as a contributing factor in division of labor, there has never been a consensus on its exact role in that process. Below, I review selected references on age polyethism in $A$. mellifera to present a more accurate historical perspective. Direct quotations are included in order to most accurately present the several authors' interpretations of their own findings with respect to the relative importance of age and environment in division of labor. Several more general reviews of 


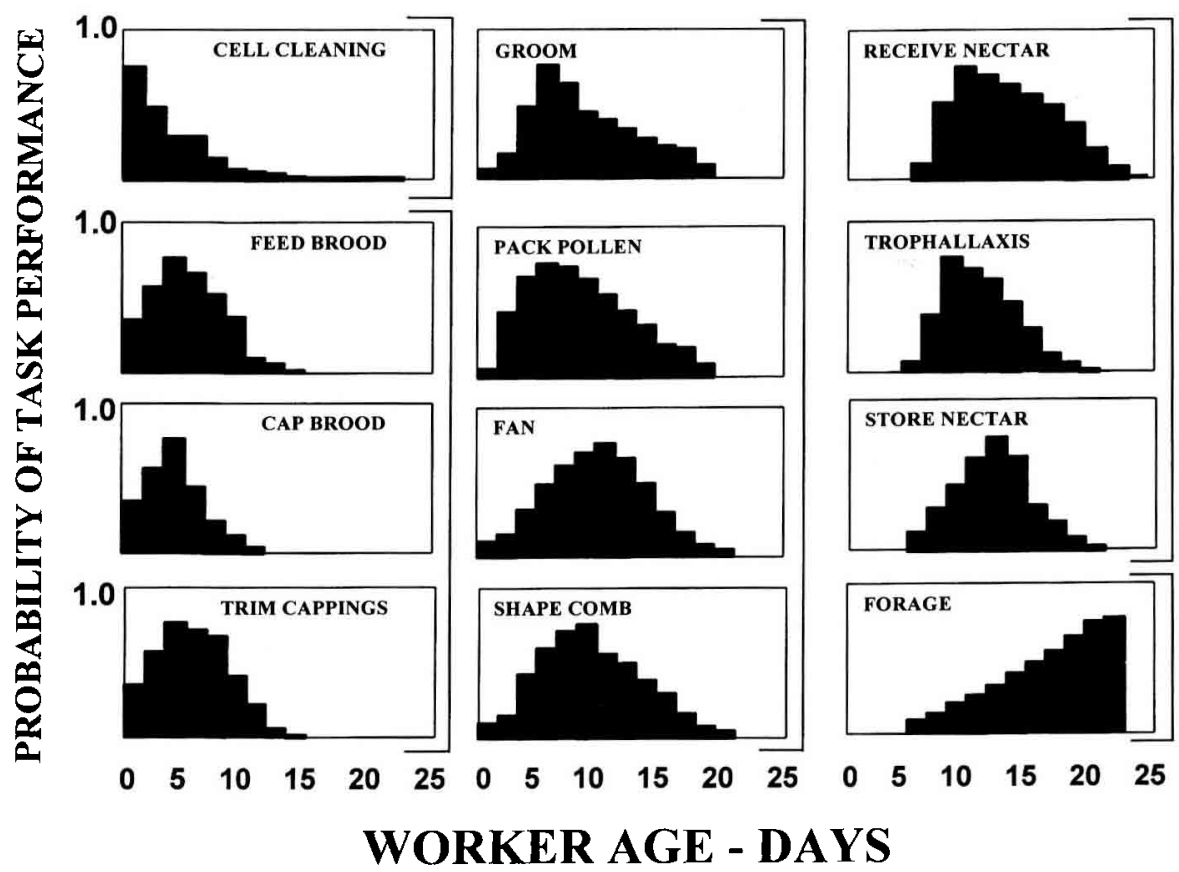

Figure 1. A stylized representation of age based division of labor in the honey bee, Apis mellifera. Tasks are grouped into five task groups each performed by workers of different ages (after Seeley, 1982).

age polyethism in the honey bee are available (Free, 1965; Winston, 1987; Page and Robinson, 1991; Robinson, 1992).

\subsection{Age effects}

\subsubsection{Early investigations of worker behavior}

Dönhoff $(1855 \mathrm{a}, \mathrm{b})$ requeened a colony of black bees with a yellow queen and noted that the yellow offspring did not forage until $17 \mathrm{~d}$ after they first emerged as adults, thereby suggesting an age-based division of labor between nest tasks and foraging tasks. Gerstung (1891-1926) proposed a rigid age-based model of task organization, but the early experimental approaches of Rösch (1925, 1927) failed to corroborate that model. Rösch observed both nest and foraging activities and noted considerable variation in the ages at which workers engaged in each task. Subsequent work with colonies in which the age distribution was restricted to either all old or all young bees demonstrated that bees of nearly any age could perform most tasks (Nelson, 1927; Himmer, 1930; Rösch, 1930).

Nolan (1924) observed that age might be involved in task selection, but noted that: "...it has not been established that every worker bee passes through each step of the life cycle of duties without omitting any". Lindauer (1952) observed that most bees (136 out of 159) actually skipped guard duty. Free (1965) suggested 
that this later finding could be a result of the particular environment in which the data were collected: a dearth of nectar might produce a somewhat higher rate of guarding.

Ribbands (1952) observed that there was "...considerable variation in which different bees, emerging on the same day and living in the same colony, commenced foraging; this age ranged from 9 to $35 \mathrm{~d}$. This variation was produced not only by altering the duration of the various hive duties, but also by omitting some of these duties". Ribbands emphasized the relationship between worker behavior and colony need: "The duties of any individual are considered to be the resultant of the requirements of the colony and the age of the individual; it is held that the requirements of the colony, which are determined by its food supply, play the predominant role". Ribbands (1952) concluded that: "Age is a factor, but not the controlling factor, in the allocation of worker duties".

Lindauer (1953) evaluated the respective roles of age and colony need. In his words: "When does a bee follow the dictates of her age, and when those of the colony? Connected with this first problem there is a second one: can a bee of a certain age do only one type of work, or can she do several types of work simultaneously? ...the results show a far-reaching fluidity in the division of labour, and support the thesis propounded by Rösch (1930) that the programme of work at any onetime is not dictated by the anatomical and physiological state of the bees, but rather by the needs of the colony". Lindauer's (1953) observations of Bee 107 "...also show that cell cleaning, brood rearing and building can, even without artificial interference, be carried out long after the age normally considered appropriate has been passed" and give further evidence of the awareness of the variation in the age at which a task can be performed.

\subsubsection{Recent investigations of worker behavior}

The causal aspect of the age-task association played a prominent role in Oster and Wilson's (1978) theoretical treatise on caste and ecology in the social insects. A caste is defined as "... any set of individuals of a particular morphological type, or age group, or both, that performs specialized labor in the colony" (Wilson, 1971). Oster and Wilson (1978) describe two paths by which behavioral ontogeny can proceed in a system based on age castes. First, the age-based response function for each task could change independently of that for each of the other tasks. This would produce a "continuous caste system' in which workers shift their attention from one task to another as they age (figure 2A). Second, the age-based response functions for some tasks may be concordant with each other, but discordant with those for other tasks or groups of tasks. This produces a system with a series of task groups (figure $2 B$ ). Workers gradually shift their attention from one task group to the next as they progress through a series of age-castes. Oster and Wilson (1978) also suggested that each task group should include tasks that can be performed in proximity to one another, thereby enhancing ergonomic efficiency. They referred to this system as a 'discrete caste system'. Wilson's $(1976,1985)$ hypothesis of 'adaptive demography' consummated the marriage of age polyethism to optimization theory, proposing that a colony's caste demography (i.e. the proportions of physical- and/or age-castes) was actually optimized for each stage of its development through colony-level selection.

Seeley (1982) applied the theoretical (Oster and Wilson, 1978) and empirical (Wilson, 1976) caste framework to the honey bee, $A$. mellifera. He proposed a series of four task groups (organized into 
three age-castes) for activities conducted within the nest and a fifth task group comprised of the various foraging activities (the fourth age-caste). Seeley showed that each task group consisted of activities that could be performed in proximity to one another, thereby maximizing ergonomic efficiency. The importance of age was emphasized: "With the honeybee colony's labor organized into four discrete age castes..." (Seeley, 1982). Seeley's concept of division of labor was one of behavioral flexibility expressed within a series of discretized (sensu Oster and Wilson, 1978) age-castes (Seeley, pers. comm.).

Age polyethism has been supported to a lesser degree by several other studies.
Winston and Punnett (1982) reported a general trend for young workers to perform nest tasks and older workers to forage. The average ages at which nest tasks were performed varied among tasks in a manner suggestive of a discretized division of labor, but no test of that hypothesis was made. Reported standard deviations for each nest tasks were ca $60 \%$ of the average age at which workers performed that task, implying a strong environmental effect on behavioral ontogeny. Kolmes (1985a, b, 1986) was unable to corroborate Seeley's system of three within-nest age-castes. Seeley and Kolmes (1991) traced the discrepancy in their findings to a difference in the way that they
A. CONTINUOUS CASTE SYSTEM
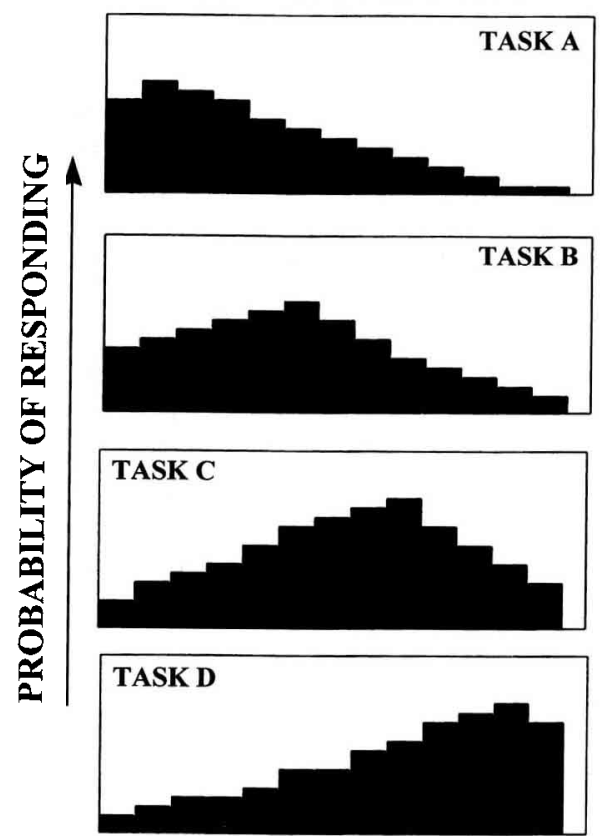

WORKER AGE - DAYS

\section{B. DISCRETIZED CASTE SYSTEM}
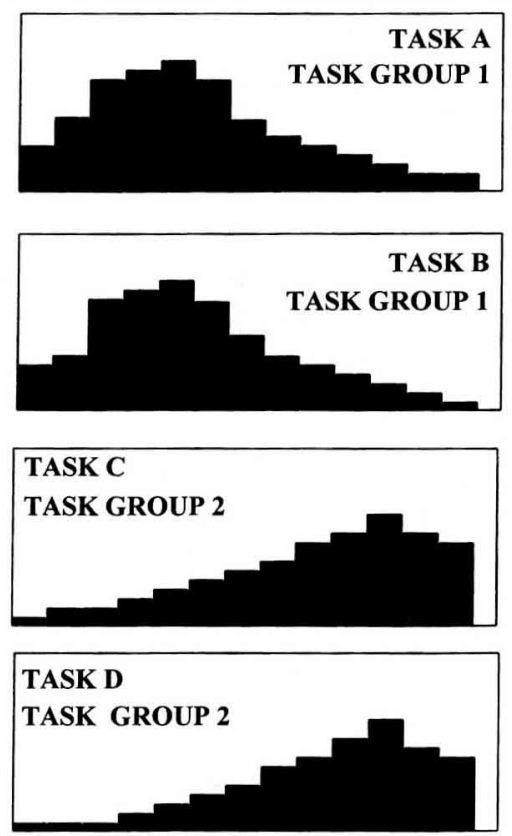

WORKER AGE - DAYS

Figure 2. Representation of two patterns of behavioral ontogeny. In the continuous task system, the response probability functions for each task vary with age independently of one another. In the discrete caste system, the response functions for two or more tasks vary with age in approximate synchrony with one another, thereby forming task groups (after Oster and Wilson, 1978). 
marked bees. Based on collaborative data, they agreed that workers went through one, and perhaps two, statistically significant transitions within the nest prior to becoming foragers. Robinson (1987a) presented data supporting within-nest transitions, but not the degree of discretization proposed by Seeley (1982). Similarly, Calderone and Page (1992) and Calderone (1995) reported a significant association between age and task performance, but did not find discrete task groups or agecastes. Winston (1987) presents a summary of the age ranges at which nest and foraging tasks have been reported to be performed.

In the above referenced studies, age effects are confounded with other potential sources of variability in worker behavior, notably environmental effects and length of time in the nest. Calderone and Page (1996) estimated age effects on the temporal pattern characterizing the transition from nest tasks to foraging tasks independent of these potentially confounding effects. Two groups of newly emerged workers held in an incubator for 7 and 14 $\mathrm{d}$, respectively, began to forage before workers from a third group that were $<1$ $\mathrm{d}$ old when all three groups were introduced to a common observation colony at the same time. These findings suggest that the 7- and 14-d-old workers had 'aged' in the incubator and support the hypothesis that there is a developmental process influencing the transition from nest to foraging tasks.

\subsection{Environmental effects on behavioral ontogeny}

Efforts to identify specific environmental factors that influence the rate of behavioral ontogeny have met with some success [reviewed in Winston (1987) and Robinson (1992)]. Winston and Punnett (1982) found that the age when workers began to forage was correlated with colony population, but not with worker age distribution or area of sealed brood. The age when workers began to care for brood was not correlated with either age distribution or area of sealed brood (Winston and Punnett, 1982). Winston and Fergusson (1985) reported that the loss of large numbers of foragers resulted in a transition to foraging by remaining workers at younger ages. They also found a weak correlation between the age when workers began to forage and the area of unsealed brood, but that finding was not confirmed in a subsequent study (Winston and Fergusson, 1986). Fergusson and Winston (1988) reported that wax deprivation induced foraging at younger ages. Naumann and Winston (1990) found that workers in afterswarms foraged at older ages than workers in primary swarms and also had a longer period of wax production.

Variability in patterns of behavioral ontogeny is evident in a variety of other situations. Milojevic (1940) induced workers to nurse for as long as $75 \mathrm{~d}$, at which time $88.7 \%$ of the surviving bees had fully or nearly fully developed hypopharyngeal (brood food) glands, typically found in much younger workers. In a reversion experiment, 28-d-old foragers were induced to regenerate both hypopharyngeal glands and wax glands, although the relative efficiency of the reverted glands was not determined. Farrar (1949) claimed to have identified bees in broodless colonies that were $395 \mathrm{~d}$ old. Maurizio (1950) reported that workers ingesting large amounts of pollen during their early life lived longer than workers deprived of pollen at that time. Perhaps the most dramatic example of environmental effects on behavioral ontogeny is the 'summer bee'-'winter bee' phenomenon [Omholt, 1988; reviewed in Fluri $(1990,1993)]$. Summer bees typically live 15-48 d while winter bees live 150-200 d [review by Fluri (1990)]. Maurizio (1950) suggested 
that the 'summer bee'-'winter bee' syndrome could be produced at any time of the year by manipulating colony conditions.

Sekiguchi and Sakagami (1966) reported variation in length of life and length of foraging life for bees under normal colony conditions. They emphasized flexibility in worker behavior and noted that: "...it is regrettable that, probably because of its simplicity, the strictly agedetermined work schedule has dominated and occasionally still contaminates popular writing...". Free (1965) attributed the popular emphasis on age to simplified reviews of Rösch's work by Rösch (1931) himself and by Morland (1930).

\subsection{Genotypic effects on behavioral ontogeny}

Winston and Katz (1982) reported that Africanized workers foraged at younger ages than European workers when workers were reared in colonies of their own race; however, European workers foraged earlier than Africanized workers when both were reared in Africanized colonies. Calderone and Page $(1988,1991)$ reported differences in the ages when workers from two strains of bees selected for high and low pollen hoarding (Hellmich et al., 1985) began to forage when maintained in a common, unrelated colony. Page et al. (1992) reported genotypic variability in rates of behavioral development among workers derived from different naturally mated queens. Genotypic variation in several life history components, including age at first foraging flight, length of foraging life and survivorship were reported by Guzman-Novoa and Page (1993) and Guzman-Novoa et al. (1994). Calderone and Page (1991) reported genotypic effects on temporal patterns of nest activity.

Under certain circumstances, including swarming and extreme stress, geno- typic effects on behavior may be more evident than under more normal situations. Kolmes et al. (1989) reported a difference of several days between workers from different patrilines (Laidlaw, 1974) with respect to the average age when they began to forage under conditions of wax deprivation, but not under non-deprived conditions. Under most conditions, the genotypic component of variation in the age at onset of foraging appears relatively small (on the order of a few days) compared to the influence of environmental effects (on the order of several weeks). However, the relative effects of genotype and environment on the age at which workers begin to forage have not been estimated.

\subsection{Specialization, fixation and omission}

Specialization, fixation and omission each demonstrate variability in individual patterns of behavioral ontogeny, and each is a well-documented phenomenon [reviewed in Robinson (1992)]. Winston and Punnett (1982) reported that a few bees performed allogrooming most of their lives. Moore et al. (1995) reported that one bee, Red 93, was seen grooming other bees $84 \%$ of the time that it was observed and never became a forager. Specialization has also been reported for "undertaking' (Visscher, 1983), water collection (Robinson et al., 1984) and grooming (Frumhoff and Baker, 1988; Kolmes, 1989), but workers do not appear to specialize on trophallaxis (Frumhoff and Baker, 1988) or attending the queen (van der Blom, 1992). Omission of tasks is also known. Guarding is performed by only a small number of colony members (Lindauer, 1952; Moore et al., 1987). Unfortunately, the tendency to focus on grouplevel behavior has masked variation in individual patterns of task performance, so the true incidence of specialization, fix- 
ation and omission remain unknown. Methods to circumvent this problem have been explored (van der Blom, 1993).

\subsection{Integration of behavior and physiology}

A worker's physiological state is intimately coordinated with its behavioral state [reviewed in Winston (1987) and Robinson and Huang (1998)]. The relationship between physiology and behavior is similar to that between morphology and behavior. However, unlike permanent morphological specializations that enable queens and workers of various species to efficiently perform specific sets of tasks throughout their lifetime, physiological specializations are generally transient, tailored to the specific task being performed at the time. Physiological correlates of worker behavior are assumed to be regulated by the same process governing behavioral ontogeny.

\subsection{Hormonal regulation of division of labor}

Considerable evidence demonstrates that transitions between many behavioral and physiological states are mediated by changes in $\mathbf{J H}$ titer [reviewed in Robinson (1992), Robinson and Vargo (1997), Fahrbach (1997) and Robinson and Huang (1998)]. Jaycox (1974) reported that newly emerged workers injected with the LawWilliams JH mimic consumed less pollen than control bees. Additionally, hypopharyngeal glands in treated bees did not develop. Treated bees left the brood nest earlier and began guarding and foraging before control bees. Effects were dose dependent. Similar results were reported using synthetic JH (Jaycox, 1976). More recently, application of the $\mathrm{JH}$ analog methoprene to newly emerged honey bees was shown to result in a rapid transition to foraging (Robinson, 1987a). Similar findings have been reported for Polybia occidentalis [methoprene - O'Donnell and Jeanne (1993)] and carpenter ants, Camponotus pennsylvanicus (Beshers and Robinson, in prep.), but not for Bombus (Pyrobombus) impatiens or B. (P.) bimaculatus [methoprene - Cameron and Robinson (1990)], although the latter two species do not exhibit strong age polyethism.

\subsection{Evolutionary considerations}

One hypothesis for the evolution of age polyethism is that it increases the efficiency of task performance, and, therefore, colony fitness (Oster and Wilson, 1978). A second hypothesis emphasizes the relationship between colony fitness and the cost of a colony's investment in each worker, a cost that must be paid back with interest to allow for colony growth (Jeanne, 1986; O'Donnell and Jeanne, 1995). The necessary return can be achieved by reducing the age at which a worker has performed sufficient work to pay back the cost of its production (through increases in efficiency) and/or by increasing average worker life expectancy. Jeanne (1986) concluded that a system in which high risk foraging tasks follow low risk nest tasks (Sakagami and Fukuda, 1968; Wilson, 1971; Porter and Jorgensen, 1981; Winston and Katz, 1982; Schmid-Hempel and Schmid-Hempel, 1984; Wilson, 1985; Guzman-Novoa et al., 1994; Visscher and Dukas, 1997) results in greater average life expectancy than a system with no temporal division of labor or one with separate nest and forager castes. A third hypothesis (WestEberhard, 1981) links the asymmetry in the risks associated with nest and foraging tasks with the degeneration in the ovaries of aging workers. Accordingly, a worker with functional ovaries spends the first part of her life in the relative safety of the nest to increase her prospects of repro- 
ducing. As she ages, her reproductive potential diminishes due to the progressive degeneration of her ovaries. At a certain age, the benefits of foraging - on inclusive fitness - outweigh the benefits of remaining in the nest awaiting an ever diminishing opportunity for personal reproduction.

\section{PROXIMATE MODELS FOR AGE POLYETHISM}

Each of the above hypotheses offers an evolutionary explanation for the existence of age polyethism. Each may apply to some species, but not to others, and each is compatible with a range of proximate mechanisms. The investigation of proximate mechanisms of division of labor, including mechanisms underlying the phenomenon of age polyethism, has recently emerged as a major focus in sociobiology (Gordon, 1996; Stuart, 1997; Bonabeau et al., 1997). Below, two candidate proximate mechanisms of age polyethism are described and discussed.

\subsection{The innate developmental program model}

Although not generally given explicit expression in the literature [but see Oster and Wilson (1978), Seeley (1982), Wilson (1985), Robinson (1987a, 1992) and Calderone and Page (1988, 1991)], one commonly held belief is that age polyethism is a result of a highly flexible, innate developmental program (IDP) that guides a worker through a sequence of tasks as it ages. The rate at which a worker progresses through this sequence and the relative frequencies at which it performs each task are determined by an interaction between the IDP and the local environment. The IDP model assumes a weak causal relationship between a worker's age and the task in which it is engaged.
Inter-individual variability in behavior not explained by differences in age is attributed to extrinsic causes, including physical and chemical cues in the nest and field environments, as well as interactions with nestmates. Essentially, the IPD model is an explanation for when workers perform tasks, not how they perform them.

In recent years, attempts have been made to integrate the extensive literature on age polyethism into a more formal and unified explanation of that phenomenon. Robinson (1985) characterized the abundant work on age polyethism and its physiological correlates as demonstrating that "... workers perform an ontogenetic sequence of tasks in the nest during their first 3 weeks of adulthood...". Robinson formulated "... a model of hormonally regulated age polyethism... As a worker bee ages she undergoes a genetically programmed change in response thresholds that is mediated by rising $\mathbf{J H}$ titers and results in the typical pattern of age polyethism..." (Robinson, 1987a). However, Robinson was clearly aware of the extensive impact the environment could have on "...the normal trajectory of behavioral ontogeny..." (Robinson, 1987a).

Calderone and Page (1988, 1991) proposed that workers pass through a series of age-castes, and that the probability of performing a specific task within an age-caste is determined by the worker's genotype, its immediate environment, and possibly by its previous experience. They suggested that a worker's genotype affects the probability of task performance in three ways: genotype may affect the rate of age-caste ontogeny, genotype may affect thresholdresponse levels for specific task-related stimuli, and genotypic effects on task performance in one age-caste may influence the probability of task performance in a subsequent age-caste.

The IDP model couples the above framework with the extensive literature demonstrating both age polyethism and 
behavioral flexibility. It can be presented more formally as a series of hypotheses: 1) there is a sequence of behavioral tasks that a worker undertakes as it ages; 2) there are often highly specific physiological correlates to a worker's behavioral state; 3 ) an endogeneous clock (e.g. Robinson's "...genetically programmed change in response thresholds that is mediated by rising JH titers...") paces behavioral and physiological ontogeny; 4) there is genotypic variability in the underlying genetic program that regulates behavioral and physiological ontogeny; 5) the rate at which a worker progresses through the task sequence is strongly influenced by the current level of local, task-related stimuli; and 6) workers exhibit considerable behavioral flexibility as demonstrated by 'accelerated' or 'retarded' development as well as by skipping of and switching among tasks and by 'reversion' to earlier tasks.

Huang and Robinson (1992) linked the IDP model to an activator-inhibitor model. The model suggests a mechanism for regulating the rate of behavioral and physiological ontogeny so as to balance a colony's age demography with its current needs. Regulation is ostensibly achieved through an interplay between an activator that promotes development $(\mathrm{JH})$ and an inhibitor substance produced by older bees (foragers) that retards development. Huang and Robinson (1996) proposed that this interplay occurs through changes in age demography. They found that young bees in triple cohort colonies (Giray and Robinson, 1994) from which older foragers had been removed began to forage sooner than young bees in similar colonies from which the removal of an equal number of bees was distributed proportionately among all three cohorts. They explained these findings as being due to a reduction in the level of the inhibitor substance resulting from the removal of the foragers.

\subsection{Critique of the IDP model}

\subsubsection{Methodological issues}

A few studies of age polyethism in the honey bee have used the focal animal technique in which a single individual is observed continuously over a period of time. More commonly, observations are made of groups of workers using some version of the scan-sample technique. Typically, a group of same-aged, marked workers is introduced to an observation colony; or, alternatively, a series of groups of same-aged workers are introduced to a colony at prescribed intervals. Workers are observed over a period of several hours to several weeks, or longer. Data are presented as the proportion of time or of observations that workers in the group(s) engaged in each activity. Studies designed to estimate foraging statistics (e.g. average age at transition to foraging, average number of foraging trips per day, or average proportion of pollen foraging trips) require markings that allow for individual identification and observations are made at the entrance. Similar methods have been used in the study of age polyethism in wasps (Jeanne, 1991).

Data collected using the above-mentioned techniques must be interpreted cautiously for several reasons (the following comments are based primarily on a review of behavioral studies, but they apply equally to physiological studies conducted using the same methods).

1) Different sources of variation are not estimated independently:

a) single age-group of workers observed over time:

i) age and environmental effects (changes in nest and field conditions) confounded; therefore, the relative contributions of these effects is unknown; 
ii) age effects confounded with the length of time a worker has been in the nest; therefore, an age effect may signify only that a worker has been in the nest long enough to have spent time working in two or more task zones;

iii) age effects confounded with previous experience; therefore, if a worker's experiences results in some degree of behavioral canalization, and if the specific pattern of canalization depends on the specific previous experiences, subsequent behavior may be biased in a highly complex manner;

b) multiple age-groups of workers introduced to a common colony at intervals:

i) age effects confounded with the length of time a worker been in the nest; consequences, as above;

ii) age effects confounded with previous experience; consequences, as above.

2) Observations of group behavior provide a picture of the average pattern of behavioral ontogeny but reveal nothing about individual patterns of task performance. For example, in the absence of a knowledge of each worker's individual identity, observations of a system in which half of the workers engage solely in task $A$ and the other half engage solely in task B would produce a data set in which the observer would not be able to differentiate between a system comprised entirely of specialists and one comprised entirely of generalists. Grouplevel observations mask other potentially important features of worker behavior including flexibility, skipping, fixation, reversion and discretization.
3) Available results provide an incomplete or non-representative picture of behavior:

a) an individual experiment conducted within a single spatio-temporal environmental window captures only the behavioral patterns typical for that specific environment and may provide an incomplete picture of the possible range of behavior;

b) an individual experiment conducted using only a few individuals or a genotypically restricted sample of workers provides an incomplete picture of the potential range of behavior.

4) Observation nests, especially those used for honey bee studies, are architecturally simplified versions of feral nests; therefore, conclusions regarding the nature of behavioral ontogeny based on studies in which such nests were used may not accurately reflect the true pattern of behavioral ontogeny in the wild.

\subsubsection{Conceptual issues}

Bourke and Franks (1995) argue that the fact that bees of widely different ages may be engaged in the same tasks (and, conversely, the fact that similarly aged workers may be engaged in different tasks) is inconsistent with any meaningful definition of age polyethism. Robinson et al. (1994) seem to agree at one point, arguing that "...it is not chronological age of the bee, per se, but its physiological age". However, an age-based physiology simply passes the problem on to another level, implying that there is some causal correlation between physiological state and age. The same arguments used against the appellation 'age-based behavior' can be used against 'age-based physiology'.

Some of the strongest evidence against a meaningful claim to an age-based model comes from studies that employed same- 
aged bees. Typically, such studies involve small colonies established with several hundred to a few thousand workers, either all newly emerged or within a few days of emergence, or all experienced foragers. Even though workers are of similar age (either all young or all old), they differentiate into nest bees and foragers within a few days, thereby demonstrating that the normal correlation between age and task performance is contingent, not necessary. Milojevic's (1940) 75-d-old nurse bees and the 'summer bee-winter bee' phenomenon are also difficult to reconcile with a meaningful reference to an agebased division of labor.

All of this raises the obvious question: at what level of environmental determinism does a system switch from being agebased to need-based? Oster and Wilson (1978) suggested that the term 'age-based' was justified because workers of different ages exhibit different degrees of responsiveness for specific tasks. However, their observation may not indicate true age-based constraints. Evidence suggest that a worker's behavioral/physiological state is characterized by some combination of selective perception of, processing of and/or selective response to specific task-related stimuli (Hersch et al., 1978; Robinson, 1987b; Breed et al., 1990; Pham-Delègue et al., 1991, 1993). Workers engaged in different tasks may be unable to respond equally when presented with a common stimulus due to physiological limitations associated with their current task [reviewed in Calderone (1998)] which is only incidentally correlated with age. Rather than focusing on the 'either/or' nature of the question, it may be more useful to view the issue in terms of averages and standard deviations. As the standard deviation increases as a percent of the average age at which a task is performed, the importance of factors other than age is clearly indicated. Even if variation in age does explain - causally - some of the variation in task performance, it does not explain all, or even most, of that variation, and other important mechanisms clearly await discovery.

The preponderance of studies focusing on group level behavior has undoubtedly contributed to a bias towards an age-based explanation of age polyethism because they emphasize averages rather than variances. This bias is seen in repeated references to young bees performing nest tasks and old bees foraging. However, young bees do forage and old bees do perform nest tasks. What can be stated more accurately is that workers perform nests tasks before they perform foraging tasks. Newly emerged bees in a normal colony do not begin to forage until they are 2-4 weeks old. Even newly emerged bees assembled into a same-age bee colony do not begin to forage for a week or more. Perhaps this pattern alone makes it difficult to discard both the terminology and the underlying belief in an age-based division of labor. The considerable variation in the age at which workers begin to forage, however, suggests that progression through the sequence is driven primarily by environmental factors, rather than by age, and that the designation 'age-based' simply reflects an uncritical evaluation of available data Age may play a role in the very broadest sense in that workers appear to begin their adult lives more competent to perform nest tasks than foraging tasks, and considerable physiological adjustments must be made prior to performing foraging tasks (Harrison, 1986). This explanation, however, represents a substantially revised role for age in division of labor.

The development of workers during the days just prior to emergence and the first few days after emergence provides additional support for a more general role for age in division of labor. Cytological changes that occur in the corpora allata of workers from emergence to $48 \mathrm{~h}$ of age (Nenadovic et al., 1985); maturation of 
the antennal complex after emergence (Masson and Arnold, 1984); increasing levels of EMG activity during the 5-7 d following emergence (Burrell and Smith, 1994); and age-dependent rates of pollen consumption (Szolderits and Crailsheim, 1993 ) all suggest that workers may spend the earliest part of adult life completing development. In addition, workers are not able to fly until about $24 \mathrm{~h}$ after emergence as adults (pers. obs.), a condition apparently related to the developmental status of the flight muscles. Sequential development of glycolytic competence in the muscles of worker honeybees is known. Hersch et al. (1978) reported that hexokinase and cytoplasmic glycerol-3phosphate dehydrogenase activities rose dramatically in the mandibular muscle of worker honeybees just prior to emergence from the sealed cells, but only developed in the thoracic muscle after emergence. Lactate dehydrogenase remained low in both muscles. Thus, glycolytic metabolism occurs in the mandibular muscles before those of the thorax, corresponding to the usual temporal pattern of muscular use and suggestive of a need to complete development by consuming protein-rich pollen immediately upon emerging as an adult.

Interpreting these data can be difficult. Each of these processes occurs in the context of specific environments, and alternative developmental pathways may exist when individuals are confronted with different environments. For example, if pollen is abundant when a worker emerges, it will consume it and go on to develop active brood food glands and nurse larvae. If pollen is in short supply, a worker cannot consume it, and, consequently, it will not develop active brood food glands and will not feed larvae. It will, however, go on to perform other tasks. It is unclear whether these outcomes represent alternate developmental path- ways, or if the latter path produces a functionally compromised worker.

\subsubsection{Activator-inhibitor hypothesis}

The activator-inhibitor hypothesis (Huang and Robinson, 1996) is not a necessary component of the IDP model. It does, however, suggest an interesting mechanism for regulating the rate of behavioral ontogeny in an adaptive manner. Evidence for the activator-inhibitor hypothesis, however, is subject to alternative interpretations. The 'accelerated' onset of foraging observed when 'older' foragers were removed from colonies (Huang and Robinson, 1996) may simply be a consequence of changes in the distribution of workers among tasks which left a 'need' that attracted the attention of some of the remaining workers [but see Robinson and Huang (1998) for another explanation]. Similarly, their finding that young bees in triple cohort colonies exhibited delayed onset of foraging when all three cohorts were artificially confined to the colony is consistent with a need-based explanation.

Experimental data are not entirely consistent with the activator-inhibitor hypothesis. Calderone and Page (1996) found that newly emerged workers introduced directly to an observation hive colony (mix of bees of all ages, including, presumably, inhibitor producing foragers) initiated foraging at the same time as, or before, sameage workers maintained in an incubator (presumably uninhibited) for several days prior to introduction to the same observation colony in two out of four trials. In one trial, the prediction of the activator-inhibitor hypothesis was supported, and in one trial, there were no significant differences between the incubator and colony groups. A candidate molecule for the inhibitor and a mechanism to explain its age-based pattern of production have not been proposed. 


\subsection{The 'foraging-for-work' model}

The impetus to find an alternative model for age polyethism has its origins in the concept of caste (Wilson, 1971). Oster and Wilson (1978) argued that a species confronted with a constant environment should have a fixed caste distribution function, thereby deriving the maximum benefits from specialization. If the environment changes substantially over a period of time greater than the worker generation time, selection should favor a flexible caste ratio. Flexibility is expressed at the colony level as an adjustment in the ratios of physical (or age) castes, and at the individual level as a worker expanding its usual behavioral repertoire (Wilson, $1980 \mathrm{a}, \mathrm{b})$, although each process has limitations. Oster and Wilson's (1978) seminal work on caste and ecology gave rise to a profusion of research emphasizing the benefits of specialization associated with caste. Recently, the emphasis has turned to the importance of individual flexibility and the mechanisms that facilitate taskswitching by workers [reviewed in Calabi (1988), Lenoir (1987) and Gordon (1989b, 1996)].

The ability to respond in a timely and appropriate manner to changes in environmental conditions that affect survival is an essential characteristic of any successful organism. Tofts and Franks (1992) argue that the environment often changes much too rapidly to be adequately addressed by colony-level adjustments to caste ratios. Further, they argue that even at the individual level "Using age to select task is a highly static method of allocating individuals' roles. Physiological aging is likely to be slow compared to changes in task demand. So any response mediated by such a mechanism will perforce be slow". This dissatisfaction with an agebased model is echoed in Bourke and Franks (1995) where the authors argue that the age-based division of labor con- cept may have "... stifled the possibility of even deeper and more general lessons being learnt from social studies. For example, because of the inflexibility inherent in such a system, this idea may have led to the under appreciation of the need for plasticity and fault tolerance in biological organization".

Recently, a new class of models that explore mechanisms of collective activities, and the complex physical structures and organizational patterns they produce [reviewed in Gordon (1996) and Bonabeau et al. (1997)] have gained prominence in the literature. These models have provided fresh insights into patterns of worker distribution among tasks (Gordon et al., 1992; Sendova-Franks and Franks, 1993; Pacala et al., 1996; Page and Mitchell, 1998), colony-level properties of homeostasis, mass response and plasticity (Page and Mitchell, 1998), dominance hierarchies (Hogeweg and Hesper, 1983, 1985; Theraulaz et al., 1995), trail networks and foraging patterns in ants (Deneubourg and Goss, 1989), the regulation of foraging behavior (Seeley et al., 1991; Camazine and Sneyd, 1991; Camazine, 1993; Seeley et al., 1996), pattern formation on nest combs (Camazine et al., 1990; Camazine, 1991), rythmical activity (Franks et al., 1990; Cole, 1991), thermoregulation (Watmough and Camazine, 1995), brood sorting (Franks and Sendova-Franks, 1992), and nest construction (Downing and Jeanne, 1988; Skarka et al., 1990).

The conceptual basis for many of these models can be traced to the physical and chemical sciences where structure is often explained using theories of self-organization (Nicolis and Prigogine, 1977). Bonabeau et al. (1997) state that "Theories of self-organization... can be extended to ethological systems, particularly social insects, to show that complex collective behaviors may emerge from interactions among individuals that exhibit simple behaviors..... there is no need to invoke 
individual complexity". Broadly speaking, these models explain collective behavior as the outcome of workers executing relatively simple behavioral algorithms in response to local environmental stimuli. Some of these models focus on the physical and chemical attributes of the nest and field environment, others emphasize the role of behavioral interactions with nestmates. Most of these collective activities appear to require either a high degree of communication among participants or a high degree of knowledge of global conditions on the part of individual workers, or both. The models associated with these activities, however, seemingly achieve their explanatory ends without the need for complex or reflective individuals.

One such model, known as 'foragingfor-work' (FFW - Tofts and Franks, 1992; Sendova-Franks and Franks, 1993), explains age polyethism without any innate age bias in task performance. Workers simply continue in their current task until opportunities for that task are reduced below a threshold value, at which time they 'forage for work'. Since workers are born in the centrally located brood area, the first tasks they perform are those related to brood care - cleaning cells, nursing and capping brood. As new workers emerge in the brood area, they begin to compete for these same tasks, thereby passively displacing workers that are older, on average, to more peripheral task zones used for different purposes and, consequently, requiring the performance of different tasks. Eventually, workers reach the outside of the nest and begin to forage. The directional gradient in the system is a consequence of new workers emerging in the centrally located brood area, and older workers dying in the most peripheral task zone, the field. The FFW model is illustrated in figure 3.

The FFW model is supported by a mathematical model (Tofts, 1993) that examines global patterns of worker dis- tribution resulting from 'individuals' following a simple behavioral algorithm for task location and task selection. The algorithm is framed in the context of a production assembly line in which products are passed through a linear series of discrete and unique task zones (comments in parentheses are mine):

1) at each step (task zone), attempt to take a task (product) from the right (perform the task), and give it (pass the product) to the left (the next task zone);

2) if successful then repeat;

3) for each direction in 1) that failed to give or take work, increment failure counter; if number of failures for a direction exceeds a threshold, then move in that direction (to the adjacent task zone) with some probability (and begin implementing the algorithm in that task zone).

Tofts (1993), using formal mathematical analysis and computer simulation, demonstrated that the model allocated workers among tasks in proportion to the amount of work available in each task zone. Tofts (1993) also demonstrated using computer simulation that the algorithm generated weak age polyethism, even though it involved no age-bias in task performance.

The conceptual basis of the FFW model, that workers are distributed among tasks in proportion to the amount of available work, is not new (references herein). It is rather reminiscent of Rösch (1927), who suggested that an abundance of workers engaged in one task would lead to transitions to other tasks. The original contributions of the FFW model rest in the identification of specific task location and task selection algorithms that workers use to navigate through task space, and in the idea that an age-neutral mechanism can, in the right environment, emulate an agebased division of labor. 


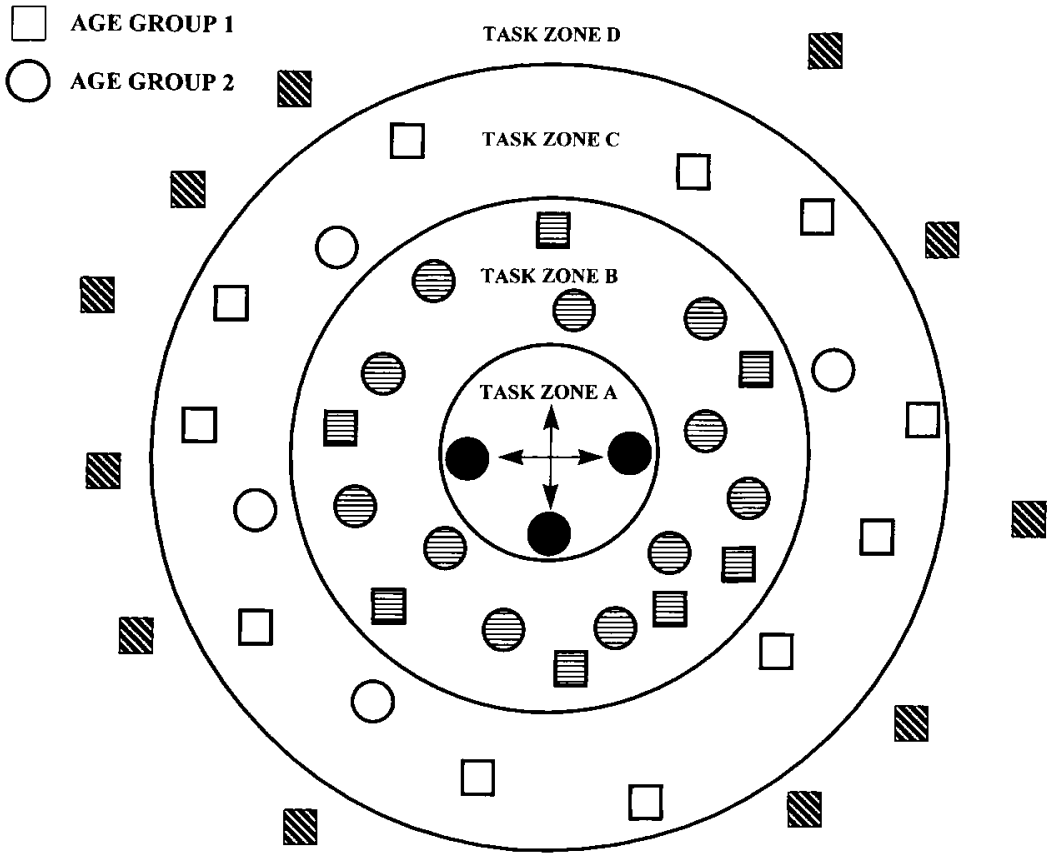

Figure 3. The 'foraging-for-work' model of age polyethism. Workers are represented by circles and squares, task zones by concentric circles. Workers perform whatever task is appropriate for the task zone in which they are currently located. Current occupation is indicated by shade of worker, which is the same for all workers in a task zone, regardless of age. Two age groups are represented. Both age-groups began life in the centrally located Task Zone A. Workers in Age Group 1 (squares) are older than workers in Age Group 2. Consequently, they have greater representation in the more peripheral task zones. Workers in Age group 2 (circles) are younger than workers in Age Group 1. Consequently, they have greater representation in the more central task zones. The outward directional gradient (arrows) is maintained by workers emerging into the system in the central task zone and dying in the most peripheral zone.

The FFW model is not a model of age polyethism, per se. Essentially, it is a model for task location and task selection. It becomes a model for age polyethism when executed in a nest in which the various colony functions are arranged in a linear series of discrete and unique task zones. Like the IDP model, the FFW model is not intended to explain how workers perform tasks. Franks and Tofts (1994) suggest that the FFW model has broad phylogenetic applicability, and Franks (1994) suggests that age polyethism, insofar as it implies a causal connection between age and task performance, is little more than a myth.

\subsection{Critique of the foraging for work model}

Published response to the FFW model has been skeptical. Criticism has focused on its failure to acknowledge the role of developmental processes in determining responses to task-related stimuli (Robinson et al., 1994), its claim of generality based solely on model output that superficially 
resembles certain biological systems (Robson and Beshers, 1997), and its claim of broad phylogenetic applicability without first considering the possible effects of variation in the way different species organize work (Traniello and Rosengaus, 1997). Here, the supportive arguments made on behalf of the FFW model are discussed, the application of the algorithm to actual task situations is evaluated, and empirical evidence that appears to run contrary to predictions of the model is presented. Its failure to accommodate known constraints on worker behavior are also explored. Lastly, a number of issues that obscure some of the valuable contributions made by the FFW model are discussed.

\subsubsection{Supportive arguments}

As discussed above, dissatisfaction with the age-based model rests on the claim that such a system is inherently inflexible and lacks sufficient flexibility to cope with real-life environmental variability (Tofts and Franks, 1992; Franks and Tofts, 1994; Bourke and Franks, 1995). Further, it is argued that physiological aging associated with even a modified 'flexible agebased system' (e.g. Calabi, 1988) also poses unacceptable limitations on a colony's flexibility. First, the literature cited herein makes it abundantly clear that flexibility is a well-recognized attribute of a worker's behavior, and that age has only infrequently been viewed as a major determinant of a worker's behavior. Second, neither empirical nor theoretical evidence is offered to suggest exactly what constitutes an unacceptable restraint on flexibility. The arguments target the costs associated with an age-based system rather than the ratio of cost to benefits. Lastly, even if age does constrain the individual, it constrains individuals of different ages in different ways (sensu Seeley, 1982). Therefore, at the colony level, there may still be an adequate number of workers available to accommodate a full range of environmental challenges.

Part of the disagreement over the appropriateness of a specific ethological system arises from the nature of the environmental contingencies referenced by different authors. Some changes in the environment occur over a period of weeks, months or more. Others take place over a period of days, hours or less. Oster and Wilson's (1978) discussion of colony-level adjustments in caste ratios and developmental patterns of caste demography clearly reference the former types of changes. Seasonally correlated changes in the environment might impose a series of predictable requirements on a colony. Colony-level adjustments in caste ratios or developmental patterns of caste demography could be one evolutionary response to those predictable changes, although available experimental evidence on the relationship between caste distributions and colony fitness is mixed [reviewed in Schmid-Hempel (1992) and Beshers and Trainello (1994)]. Proponents of the FFW model (Tofts and Franks, 1992; SendovaFranks and Tofts, 1993; Franks and Tofts, 1994), on the other hand, are clearly referencing changes that occur over a relatively short period. Oster and Wilson (1978) were not suggesting that colonylevel adjustments in caste ratios would be an effective way to deal with changes on that scale.

\subsubsection{Restrictions on model's generality}

The actual algorithm (Tofts, 1993) is considerably more precise and, therefore, limited in terms of similarities to existing task systems, than the verbal presentation of the FFW model. Bourke and Franks (1995) talk about an unemployed ant 'wandering' in search of work. This is quite different from the well-specified 'left-right' choice used in the one-dimen- 
sional, assembly-line model. In the honey bee, some tasks can, perhaps, be viewed within the assembly line framework (e.g. a nectar forager passing on nectar loads to a receiver bee), but most cannot. Task opportunities do not generally come to the individual, rather, the individual goes to the task. Once one leaves the one-dimensional world of the FFW model, one is immediately confronted by the lack of clues suggesting how to implement (test) the 'wandering' (i.e. task location) algorithm in multi-dimensional task space.

Further departures from the one-dimensional character of the model are suggested by the extensive use of signals and cues (Lloyd, 1983; Seeley, 1995) in the process of task selection. For example, workers may be recruited to foraging via an encounter with a dance (a signal), not by being displaced out the front door. Similarly, the quantity and quality of food exchanged during trophallaxis has the potential to convey considerable information about a colony's current state (Wilson and Eisner, 1957; Nixon and Ribbands, 1952; Free, 1957, 1961; Sorensen et al., 1985). Pollen foragers may sense the need for pollen indirectly through the quality of the food they receive (a cue) during food exchange with nurse bees. Recently, several studies have demonstrated the transmission of proteins from nurse bees to other colony members, including foragers (Crailsheim, 1990 , 1991, 1992; Hrassnigg and Crailsheim, 1996). Experimental evaluation of the mechanisms regulating pollen collection support the role of such cues as indicators of task need (Camazine, 1993).

The FFW algorithm (Tofts 1993) links the traditional concept that need determines the distribution of workers among tasks, to a relatively restrictive algorithm that maps onto only a subset of possible tasks. These are tasks exhibiting a high degree of task partitioning (Jeanne, 1986, 1991), such as those involved with resource acquisition and processing. The algorithm, in its current form, appears to be incompatible with other parts of a colony's task structure. A more thorough evaluation of the underlying concept of the FFW model will depend on the identification of task location and selection algorithms that govern other task situations.

\subsubsection{Empirical evidence}

Available empirical evidence brings into question the extent to which the FFW model serves as a general explanation for how workers locate and select tasks. As mentioned, tasks associated with resource acquisition and utilization often seem to fit within the linear framework of the Toft's (1993) algorithm. That fact alone, however, does not demonstrate that the FFW model is the correct model. Seeley (1989) found that as nectar intake rises, a nectar forager faces an increase in the time it takes to locate a receiver bee to unload its nectar. The FFW model would seem to predict that a nectar forager in that circumstance would respond by switching to receiving nectar. This is not the case. Instead, a nectar collector unable to unload her cargo performs a tremble dance (Seeley et al., 1996) which signals middleaged and young bees to switch to receiving nectar. Many receiver bees actually respond to being 'overloaded' by nectar foragers by switching to nectar foraging (Seeley, 1995), clearly not predicted by the FFW model. Seeley (1995) suggests that these discrepancies might be accommodated by a modified version of the FFW model.

Other findings question the generality of the FFW algorithm as an explanation for age polyethism. Trainello and Rosengaus (1997) note that the termite, Zootermopsis angusticollis (Rosengaus and Trainello, 1993), and the ponerine ant, Amblyopone pallipes (Trainello, 1978), 
appear to meet the requirements of the model, in that they have structured nests, but lack age polyethism. These findings suggest that a closer look at the relation between age polyethism and nest architecture in different taxa may be productive in assessing the role of the FFW model.

\subsubsection{Constraints on behavior}

The FFW model assumes that there are no significant constraints on a worker's ability to select and perform a task. Yet, there are existing constraints evident in insect societies attributable to several sources:

1) those inherent in the biology of the system due to physiological constraints (discussed in Robinson et al., 1994);

2) those resulting from developmental canalization, such as physical castes (Oster and Wilson, 1978);

3) those associated with phylogeny [discussed in Trainello and Rosengaus (1997)].

\subsubsection{Physiological constraints}

Evidence contradicts the notion that workers are completely flexible. Physiological response time is a common feature of many aspects of behavioral ontogeny and appears to influence patterns of worker allocation among tasks. Differentiation of same-aged bees into nest bees and foragers takes several days, suggesting physiological limitations on response time. Robinson and Page (1995) showed that the rate of removal of dead bees from a colony decreased significantly for several days after 'undertaker' bees were removed, suggesting a physiological constraint regulating the development of new 'undertakers'. The likelihood of reverting from foraging to nursing has also been show to be dependent on the length of time that a worker has been foraging
(Robinson et al., 1992), reflecting the degree of physiological commitment to one's current task. Selection may have minimized response time, but it has not eliminated it.

Certain physiological states appear to be compatible with some tasks, but incompatible with others. Harrison (1986) reported numerous physiological changes that mark the transition from the nest phase to the foraging phase. This may explain why field bees may engage in one or more foraging tasks, or they may become scouts (Seeley, 1985); and why nest bees often perform several nest tasks over a relatively brief interval (references cited herein). Except for the initial transition from nest to foraging tasks, however, workers do not generally switch between these two main task groups, suggestive of physiological constraints associated with their current task.

Other findings support the hypothesis that a worker in a given behavioral/physiological state exhibits selective perception of, processing of and/or response to task-related stimuli. Perception of alarm pheromone is also known to be age dependent (Robinson, 1987b). Olfactory-based behavioral response to queen mandibular pheromone blends and extracts is also age dependent, being greatest in workers $\leq 5 \mathrm{~d}$ old (Pham-Delègue et al., 1991, 1993). These findings suggest that the process of task selection is more complex than that portrayed by the FFW model and that physiological constraints play an important role in determining which bees respond to which tasks.

\subsubsection{Developmental canalization}

In the highly eusocial insect societies, queens and workers have undergone dramatic reductions in flexibility (increases in specialization). Clearly, these limitations reflect a compromise between the costs resulting from the loss of individual flexibility and the benefits arising from 
increased specialization. In this case, the later apparently outweigh the former. Similarly, the existence of physical worker castes in ants and termites also argues against the claim that flexibility is always paramount. The fact that $20 \%$ of ant genera have morphological castes (Oster and Wilson, 1978) demonstrates that reductions in individual capacity can be favored by natural selection under certain circumstances. A meaningful conclusion regarding the relative values of generalist and specialist strategies must be based on a cost-benefit analysis and on an empirical understanding of the compatibility of physiological states required to perform different tasks. However, neither are provided, and it seems unlikely that such an analysis could be generalized over all social species.

\subsubsection{Phylogenetic constraints}

The social insect fauna are distinguished from each other by a variety of individual and colony-level traits, reflecting the variability among the environments in which each species evolved. Each species arrives at a unique set of solutions to its environment, and each solution set is achieved within an historical context, reflecting the limits of available genetic variation in the evolving population. The importance of these considerations in the evolution of the organization of work is largely unknown. Given the considerable variability in the way that different species construct nests, organize the acquisition and utilization of resource and care for young, it seems premature to accept a single behavioral algorithm as an adequate explanation for all patterns of worker allocation among tasks. Trainello and Rosengraus (1997) suggest that a comparative socio-ecological approach to the study of division of labor that emphasizes the effects of variation in local environments and phylogenetic histories on patterns of organization of work is essential to pro- vide the necessary empirical substrate from which general patterns may emerge.

\subsubsection{4. 'Species gap'}

Franks and Tofts (1994) explanation that older bees respond disproportionately to a brick dropped on a colony (Breed et al., 1990) because older bees are most likely to be near the entrance indicates a 'species gap' in the understanding of architectural patterns in different taxa. An examination of the honey bee nest (Seeley and Morse, 1976) provides no obvious clues as to why older bees should be located nearer to the entrance than younger bees as suggested by Franks and Tofts (1994).

\subsubsection{Unresolved issues}

Attempts are made to accommodate the full range of behavioral phenomena, including fixation, learning and genoptypic variability, within the framework of the FFW model. Unfortunately, these efforts lead to some uncertainty about the operation of the model.

\subsubsection{Fixation}

The model allows for fixation by individuals, so long as the number of generalists is sufficient to cope with any changes and the nest can still allocate individuals to roles efficiently. However, a similar argument could be made for age and physical castes: age and physical castes are permissible so long as their decreased flexibility does not impose costs that outweigh the benefits of increased specialization.

\subsubsection{Learning}

Learning results in greater efficiency and experienced workers take tasks away from naive workers (Bourke and Franks, 1995). Yet, it is argued elsewhere (Tofts and Franks, 1992) that young workers displace older workers. The exact impact of learning on the model is unclear. Different 
patterns of age polyethism should emerge from the model, depending on whether experienced workers take work away from naïve workers, or whether young workers displace older workers.

\subsubsection{Genotypic variability}

Franks and Tofts (1994) seem concerned with eliminating competing mechanisms that might provide an explanation for division of labor. Although genotypic variation may serve as an organizing principle in certain situations (Calderone and Page, 1992), the study of genotypic variation in worker behavior has been conducted primarily to determine which behavioral traits exhibit heritable variation and are, therefore, capable of being shaped by selection (Calderone and Page, 1991).

Franks and Tofts (1994) analysis of the role of genotypic variation in determining patterns of task performance is not clearly related to their overall argument for the FFW model: "For example, a worker of a particular genotype specializing in removing its dead nestmates ... may be doing so not through an innate preference but simply because such work tends to be neglected by others". This argument begs the question - why are others neglecting it? While their argument might be used to explain why one individual fails to remove dead nestmates, it cannot explain why a group of related (i.e. genotypically similar) workers neglect a particular task, while workers belonging to a different group of related workers perform the task. They suggest that genotypic variability in task performance results not from an innate preference for a specific task, but from variation in response thresholds to task-related stimuli. This alternative is the stimulus-threshold model previously proposed by Calderone and Page (1988) and Robinson and Page (1989) as an explanation for genotypic variability in task performance.
Calderone (1995) proposed an interpretation of genotypic variability more supportive of the FFW model. Betweengroup variation in the age when workers begin to forage is often reported as genotypic variation in the rate of age-caste ontogeny, implicitly assuming that there is age-caste ontogeny. However, this variation could simply reflect genotypic variation in the probability of performing specific tasks resulting either from variation in response thresholds for task-related stimuli or variation in failure thresholds for specific tasks, or both. Depending on an individual's genotype and the specific nest environment, it would move through task zones more or less quickly than workers with different genotypes. Therefore, genotypic variability in rates of behavioral ontogeny cannot be cited as sufficient evidence for an age-based system of task allocation.

\section{CONCLUSIONS}

The value of any model rests in its ability to accurately predict future states of the system being modeled. Models of social behavior are only beginning to exhibit that capability, reflecting the fact that our understanding of the underlying task structure and the mechanisms regulating task-switching is sparse and imperfect. Research has often described social behavior with broad strokes. A unified model of behavioral and physiological ontogeny will require a much more detailed understanding of the fine structure of behavior than is presently available.

The current dialogue has helped to clarify some aspects of behavioral and physiological ontogeny in cavity-dwelling honey bees. According to the IDP model, a worker honey bee progresses through a sequence of tasks as it ages. The available evidence suggests that the sequential 
nature of the model is partially justified, but the role of age, as a causal factor, is unclear. A more conservative interpretation of the data is that behavioral ontogeny is characterized by two phases - a nest phase followed by a foraging phase. There is evidence that workers perform nest tasks before they perform foraging tasks and that this represents a developmental, albeit reversible, sequence. This sequence may reflect the fact that workers emerge more competent to perform some nest tasks than any foraging task or, that they must complete development during early adult life. The rate at which a worker progresses from the nest phase to the foraging phase is determined by its genotype, the environment and probably stochastic events, as well, although the relative contributions of these sources of variation, the specific environmental factors, and the mechanisms by which workers interact with those environmental factors remain largely unknown [but see Seeley (1995) for a review of mechanisms regulating nectar and pollen foraging in the honey bee]. The hypothesis that the ontogeny of nest tasks follows a prescribed sequence is less certain and requires further study.

The FFW model - that tasks allocate workers (Franks and Tofts, 1994) - is an interesting implementation of the traditional concept that workers respond primarily to the needs of their colony. The specific algorithm (Tofts, 1993), however, is too restrictive to be applicable in many task situations. Further, it is inconsistent with the available evidence on how workers actually locate and select tasks in some contexts where it might be expected to apply. The FFW model also underestimates the significance of physiological and developmental constraints on task selection. Therefore, the model cannot serve as a general explanation for task location and selection or for age polyethism, although it may apply to some task situations in some species. The algo- rithm has considerable heuristic value, however, in that it demonstrates that an age-neutral mechanism can emulate an age-based pattern of task performance under certain conditions. Future studies of age polyethism must consider the possible effects of age-neutral mechanisms on patterns of behavioral and physiological ontogeny.

The FFW debate has also raised serious issues pertaining to the role of modeling in investigations of biological systems. Robson and Beshers (1997) point out that "A variety of systems can display similar global patterns, yet possess dissimilar organization, so claims of similar organization based on phenomenological similarity alone are inadequate". A particular algorithm, e.g. FFW, may generate a reasonable facsimile of a real behavioral pattern; yet, it may reveal nothing about how any particular system produces that pattern. One way to circumvent this criticism is to begin the modeling process by identifying algorithms actually used by workers of a given species, then incorporating those algorithms into a model that can evaluate their effect on global patterns of worker distribution.

Much of the controversy over the FFW model is attributable to the author's claims of generality, rather than with the model and it conceptual basis. Clearly, age is an inadequate explanation for age polyethism and other mechanisms are involved. The FFW algorithm may apply in some contexts; however, it serves neither as a general mechanism for task location and selection nor for age polyethism. A unified model of behavioral and physiological ontogeny will undoubtedly include multiple mechanisms for task location and selection, reflecting the complex and often non-linear nature of a colony's task network. Physiological and developmental processes also play a significant role in determining which workers respond to task related stimuli. Age may play a role in 
division of labor, but the variability evident in the process of behavioral and physiological ontogeny clearly demonstrates that other mechanisms of equal or greater importance await discovery.

\section{ACKNOWLEDGEMENTS}

I thank Jennifer Fewell, Cole Gilbert, Bas Kuenen, Kern Reeve, Gene Robinson and Tom Seeley for simulating conversations and Stefan Fuchs and three anonymous reviewers for their significant efforts and valuable comments on the manuscript.

\section{Résumé - Approche des mécanismes du polyéthisme lié à l'âge chez l'abeille mellifère, Apis mellifera L. Le poly-} éthisme lié à l'âge est l'un des caractères les plus marquants de la division du travail chez les insectes sociaux. Une étude de la bibliographie concernant l'abeille mellifère révèle que « le besoin de la colonie » est généralement considéré comme un facteur déterminant du comportement de l'ouvrière plus important que l'âge. Néanmoins la composante temps sous-jacente, qui guide l'ontogenèse comportementale et physiologique, reste une caractéristique perceptible de l'explication traditionnelle du polyéthisme lié à l'âge. L'interprétation la plus courante du polyéthisme lié à l'âge, le modèle de programme de développement inné (ou IDP), peut se résumer ainsi : 1) il existe une suite de tâches comportementales qu' une ouvrière accomplit au cours de sa vie ; 2) il existe souvent des corrélats physiologiques fortement spécifiques liés à un état comportemental d'une ouvrière ; 3 ) une horloge interne (cf « des modifications du seuil de réponse programmés génétiquement, causés par une augmentation de la teneur en $\mathrm{HJ} \gg$ de Robinson) détermine le déroulement de l'ontogenèse comportementale et physiologique ;4) il existe une variabilité phénotypique dans le programme génétique sous-jacent qui régule l'ontogenèse com- portementale et physiologique ; 5) la vitesse à laquelle une ouvrière progresse dans la séquence des tâches est fortement influencée par le niveau des stimuli locaux en relation avec les tâches ; et 6) les ouvrières présentent une flexibilité comportementale considérable, comme le montrent le développement accéléré ou retardé, le saut de certains tâches, l'aiguillage d'une tâche vers une autre ou le retour à des tâches antérieures. La preuve qui soutient la relation causale entre âge et accomplissement d'une tâche est fragile. Les études sur le polyéthisme lié à l'âge ont généralement été conçues pour estimer les effets de l'âge indépendamment d'autres sources de variabilité. De plus, la variabilité dans l'âge auquel on a observé les ouvrières accomplir les différentes tâches, met en question la notion d'une référence significative à la relation causale entre âge et comportement.

Le modèle FFW (foraging for work, chercher du travail) offre une alternative conceptuelle au modèle IDP, mais ce n'est qu'une alternative au concept. Il explique l'existence du polyéthisme lié à l'âge comme un type émergent qui résulte du comportement des individus aus sein du nid selon quelques règles simples. Ce comportement est structuré par une suite de zones fonctionnelles séparées, chacune étant consacrée à une tâche unique. Ce modèle ne suppose aucune relation innée avec l'âge dans la probabilité d'accomplir une tâche. Les ouvrières poursuivent simplement la tâche en cours jusqu'à ce que les occasions de l'accomplir descendent au-dessous d'un seuil ; à ce moment elles cherchent du travail. Puisque les ouvrières naissent dans le nid à couvain situé au centre de la colonie, les premières tâches qu'elles accomplissent sont celles en relation avec le soin au couvain - nettoyage des cellules, nourrissage et operculation du couvain. Au fur et à mesure que dans le nid naissent de nouvelles ouvrières, celles-ci commencent à entrer 
en compétition pour ces mêmes tâches et déplacent alors les ouvrières qui sont, en général, plus âgées vers des zones de tâches plus périphériques utilisées pour des besoins différents et nécessitant, en conséquence, l'accomplissement de tâches différentes. Finalement les ouvrières atteignent le bord extérieur du nid et se mettent à butiner. Le gradient de direction centrifuge du système est maintenu par le fait que les ouvrières arrivent dans le système dans sa partie centrale et qu'elles meurent dans la zone de tâches périphériques, le champ. Ce processus a pour conséquence une répartition des ouvrières entre les tâches qui n'est que faiblement en rapport avec l'âge, même si le modèle ne présuppose aucune relation innée avec l'âge.

Le modèle FFW est une remise à neuf très limitée du concept traditionnel, selon lequel les ouvrières répondent principalement aux besoins de la colonie. Les algorithmes spécifiques du repérage et du choix des tâches sont trop restrictifs pour pouvoir être appliqués dans de nombreuses situations. En outre, ils ne concordent pas avec ce qui se passe réellement dans des situations où l'on pourrait s'attendre à ce qu'ils s'appliquent. Le modèle FFW sousestime également l'importance des contraintes physiologiques et comportementales dans le choix des tâches. Il ne peut donc pas servir d'explication générale pour le repérage et le choix des tâches, ni pour le polyéthisme lié à l'âge, bien qu'il puisse s'appliquer à certains tâches. Pourtant le modèle FFW a une valeur heuristique considérable, puisqu'il démontre que le mécanisme neutre par rapport à l'âge peut dans certaines conditions engendrer un type de répartition des tâches basé sur l'âge. Les études futures doivent prendre en considération les effets possibles de tels mécanismes neutres par rapport à l'âge sur l'ontogenèse comportementale et physiologique.

Le dialogue actuel a aidé à clarifier quelques aspects de l'ontogenèse com- portementale et physiologique chez les abeilles qui nidifient dans des cavités. Selon le modèle IDP, une ouvrière progresse dans une séquence de tâches au cours de sa vie. Les preuves existantes suggèrent que la nature séquentielle de ce modèle est particulièrement justifiée, mais que le rôle de l'âge comme facteur causal n'est pas clair. Une interprétation plus conservatrice des données est que l'ontogenèse du comportement se caractérise par deux phases : une phase à l'intérieur du nid, suivie d'une phase de butinage. Il y a des preuves évidentes que les ouvrières accomplissent les tâches domestiques avant les tâches de butinage et que cela représente une séquence de développement. La vitesse à laquelle une ouvrière progresse dans la séquence est déterminée par son génotype, l'environnement et probablement des événements fortuits, mais les contributions relatives de ces sources de variation, des facteurs spécifiques du milieu et des mécanismes par lesquels les ouvrières interagissent avec les facteurs du milieu restent dans une large part inconnues. L'hypothèse selon laquelle l'ontogenèse des tâches domestiques suit une séquence imposée est plus difficile à prouver et nécessite d'autres études.

Le débat sur le modèle FFW a soulevé des questions importantes concernant le rôle de la modélisation dans l'étude des systèmes biologiques. Robson et Beshers (1997) soulignent qu' « une variété de systèmes différents peut présenter des types globaux semblables et posséder néanmoins une organisation différente, si bien qu'affirmer l'existence d'une organisation semblable uniquement sur la base d'une similarité phénoménologique est insuffisant ». Un algorithme particulier, par exemple le modèle FFW, peut générer un facsimilé acceptable du comportement sans pour autant fournir d'indications sur la façon dont un système réel produit ce type. Un moyen pour le modélisateur de 
contourner cette critique est d'identifier d'abord des algorithmes réellement utilisés par les ouvrières d'une espèce donnée, puis de les incorporer dans un modèle destiné à évaluer leur effet sur les types globaux de la répartition des ouvrières.

Une bonne partie de la controverse sur le modèle FFW peut être attribuée à l'affirmation par les auteurs de sa valeur générale et universelle, plutôt qu'au modèle lui-même ou à ses bases conceptuelles. II est clair que l'âge seul ne suffit pas à expliquer le polyéthisme lié à l'âge, comme l'affirment à juste titre les défenseurs des mécanismes neutres par rapport à l'âge. Il est tout aussi clair que les processus physiologiques et comportementaux jouent un rôle important pour déterminer quelles ouvrières répondent aux stimuli liés aux tâches et que ces processus marquent une certaine limite à la flexibilité individuelle. Finalement les deux types de mécanismes, celui basé sur l'âge et celui qui en est indépendant (comme l'algorithme FFW), pourraient jouer un rôle dans l'explication du type observé du polyéthisme lié à l'âge. (C) Inra/DIB/AGIB/Elsevier, Paris

\section{Apis mellifera / comportement social / polyéthisme / auto-organisation / pro- priété émergente}

\section{Zusammenfassung - Proximate Mecha- nismen der altersabhängigen Arbeits- teilung bei Honigbienen, Apis mellifera} L. Die altersabhängige Arbeitsteilung ist die hervorstechendste Eigenschaft der Aufteilung der Aufgaben in Insektensozietäten. Eine Durchsicht der Literatur über Honigbienen zeigt allerdings, daß die Bedarfslage der Völker generell als wichtigerer Faktor angesehen wird als das Alter der Arbeiterinnen. Dessen ungeachtet bleibt im Kern die zeitliche Führung der Ontogenie des Verhaltens und der Physiologie eine erkennbare Charakteristik in der traditionellen Erklärung altersabhäng- iger Arbeitsteilung. Der verbreitetste Erklärungsansatz altersabhängiger Arbeitsteilung ist das angeborene Entwicklungsprogramm (innate developmental program model, or IDP). Dieses kann folgendermaßen zusammengefasst werden: 1) Die Arbeiterinnen führen während ihres Älterwerdens eine aufeinanderfolgende Reihe von Verhaltensaufgaben durch; 2) oft gibt es hochgradig spezifische physiologische Korrelate zu dem jeweiligen Verhaltenszustand einer Arbeiterin; 3) eine endogene Uhr (z.B. Robinson's “...genetisch programmierte, durch steigende JH-Titer hervorgerufene Änderungen der Antwortschwellen...") bestimmt den Ablauf der Ontogenie des Verhaltens und der Physiologie ; 4) das der Regulation dieses Ablaufs zugrundeliegende genetische Programm zeigt genetische Variabilität; 5) die Geschwindigkeit, mit der eine Arbeiterin eine Reihe von Arbeiten durchläuft, wird stark durch die jeweiligen lokalen, aufgabenbezogenen Reize beeinflusst; und 6) die Arbeiterinnen zeigen ein erhebliches Maß an Verhaltensflexibilität, wie sie durch 'beschleunigte' oder 'verzögerte' Entwicklung sowie durch das Auslassen von oder Umschalten zwischen Aufgaben oder der 'Umkehrung' zu früheren Aufgaben gezeigt wird.

Es gibt nur ausserordentlich begrenzte Belege für eine ursächlichen Verbindung zwischen Alter und Aufgabenerfüllung. Die Untersuchungen der altersabhängigen Arbeitsteilung waren oft nicht auf eine getrennte Abschätzung der Auswirkung von Alterseffekten von anderen Einwirkungen ausgelegt. Weiter stellt die Unterschiedlichkeit des Alters, in dem Arbeiterinnen bei der Ausübung der unterschiedlichen Aufgaben beobachtet wurden, die Behauptung einer bedeutsamen Beziehung zwischen Alter und Verhalten in Frage. Allerdings legen einige Beobachtungen des Arbeiterinnenverhaltens, insbesondere während der ersten Tage des Erwachsenenlebens, ein auf dem 
Alter basierendes Verhaltensprogramm sehr nahe und verdienen eine genauere Untersuchung.

Das FFW-Modell (foraging for work, nach Arbeiten suchen) bietet eine konzeptionelle Alternative zu dem IDPModell, es bleibt allerdings nur ein alternatives Konzept. Es erklärt die Tatsache einer altersabhängigen Arbeitsteilung als ein emergentes Muster, das sich aus dem Verhalten der Einzeltiere nach wenigen einfachen Verhaltensregeln von selbst ergibt. Diese Verhalten findet innerhalb eines Nestes statt, das durch eine einer linearen Abfolge getrennter Aufgabenzonen mit voneinander unterschiedlichen Aufgaben strukturiert ist. In dem Modell werden keinerlei angeborene Altersbevorzugungen für diese Arbeiten vorausgesetzt. Die Arbeiterinnen setzen einfach ihre derzeitige Tätigkeit solange fort, bis die Gelegenheiten für diese Tätigkeit unter einen bestimmten Schwellenwert sinken, woraufhin sie 'nach Arbeiten suchen'. Da die Arbeiteinnen in dem zentral gelegenen Brutnest geboren werden, sind brutpflegebezogene Aufgaben die ersten, die sie ausführen - das Reinigen der Zellen, das Füttern und das Verdeckeln der Brut. Sobald neue Arbeiterinnen schlüpfen, konkurrieren sie um ebendiese Aufgaben und verdrängen damit Arbeiterinnen, die im Mittel älter sind, in die mehr außen gelegenen Aufgabenzonen. Diese dienen andersgearteten Zwecken und erfordern daher die Ausführung anderer Arbeiten. Letztendlich erreichen die Arbeiterinnen den Aussenbereich des Nests und beginnen mit dem Futtereintrag. Der nach außen gerichtete Gradient des Systems wird dadurch aufrechterhalten, daß die Arbeiterinnen im zentralgelegenen Brutnestbereich geboren werden und in der am weitesten aussen gelegenen Aufgabenzone, dem Freiland, sterben. Dieser Vorgang hat eine leicht altersbezogene Verteilung der Arbeiterinnen zur Folge, obwohl das
Modell zunächst keine angeborene Altersabhängigkeit des Verhaltens annimmt.

Das FFW-Modell stellt eine weitgehend umschriebene Ausarbeitung des nützlichen, aber traditionellen Konzepts dar, nach dem Arbeiterinnen hauptsächlich auf die Erfordernisse ihres Volkes reagieren. Die spezifischen Vorgehensweisen bei der Berechnung der Entdeckung und der Auswahl der Aufgaben sind für eine Anwendung auf die meisten realen Aufgaben zu eng gefasst. Weiter stimmen sie bei Situationen, auf die sie möglicherweise angewendet werden könnten, nicht mit den bestehenden Kenntnissen darüber überein, wie Arbeiterinnen tatsächlich Aufgaben entdecken und auswählen. Das FFWModell unterschätzt weiterhin die Stärke physiologischer Beschränkungen auf die Wahl der Aufgaben. Es kann daher nicht als generelle Erklärung für die Entdeckung von Aufgaben und für die altersabhängige Arbeitsteilung herhalten, obwohl es für manche Aufgaben zutreffen könnte. Das FFW-Modell hat allerdings erheblichen heuristischen Wert, da es demonstriert, daß ein altersneutraler Mechanismus unter bestimmten Bedingungen ein alterskorreliertes Muster der Aufgabenverteilung erzeugen kann. Der Gesichtspunkt, daß Arbeiterinnen als Folge kompetitiver Verdrängung dazu tendieren, vom Brutbereich aus nach außen zu wandern, verdient eine weitere Untersuchung. Die möglichen Effekte solcher altersneutralen Mechanismen auf das Muster der Ontogenie des Verhaltens und der Physiologie müssen in zukünftige Studien der altersabhängigen Arbeitsteilung berücksichtigung finden.

Der derzeitige Dialog hat dazu beigetragen, einige Aspekte der Ontogenie des Verhaltens und der Physiologie bei höhlenbrütenden Honigbienen zu klären. Nach dem IDP-Modell durchschreitet eine Arbeiterin während ihres Älterwerdens eine Reihe von Aufgaben. Der vorliegede Kenntnisstand legt nahe, daß die im 
Modell enthaltene Zeitabfolge teilweise gerechtfertigt ist, die Rolle des Alters als kausaler Faktor ist allerdings unklar. Eine etwas zurückhaltendere Interpretation der Daten ist, daß die Ontogenie des Verhaltens durch zwei Phasen gekennzeichnet ist - eine Innennestphase, die von einer Nahrungssuchenden Phase gefolgt wird. Es gibt deutliche Belege, daß Arbeiterinnen Innennestaufgaben nachgehen, bevor sie Sammelaufgaben ausüben, und daß dies eine entwicklungsbedingte Aufeinanderfolge darstellt. Die Geschwindigkeit, mit der eine Arbeiterin durch diese Aufgabenfolge fortschreitet, wird durch ihren Genotyp, die Umgebung, und wahrscheinlich auch noch durch Zufallsereignisse bestimmt. Die relativen Beiträge dieser Ursachen für die Unterschiedlichkeiten, die Umgebungsfaktoren im Einzelnen und die Mechanismen, nach denen die Einzeltiere mit diesen Umgebungsfaktoren interagieren, sind im großen und ganzen unbekannt. Die Hypothese, nach der für die Ontogenie der Aufgaben innerhalb des Nests eine vorgegebene Reihenfolge besteht, ist wesentlich schwieriger zu belegen und bedarf weiterer Studien. Zwei weitgefaßte Ziele zukünftiger Untersuchungen sind die Mechanismen, die der Nest-Sammel-Abfolge zugrundeliegen, und die Kennzeichnung der organisatorischen Strukturierung der Innennestaufgaben. Dies schließt die Bestimmung von außen wirkender Faktoren ein, die die Ontogenie der Innennestaufgaben regulieren.

Die Bestimmung der Mechanismen, anhand derer die Arbeiterinnen durch den Aufgabenraum navigieren, stellt einen weiteren wichtigen Bereich für Untersuchungen dar. Hier können sowohl altersabhängige wie altersneutrale Faktoren eine Rolle spielen. Hierbei muß angemerkt werden, daß das FFW-Modell die Annahme altersabhängiger Einschränkungen des Verhaltens nicht ausschließt.
Die Debatte um das FFW-Modell hat wichtige Fragen bezüglich der Rolle von Modellrechnungen in Untersuchungen biologischer Systeme aufgeworfen. Robson and Beshers (1997) haben aufgezeigt, daß "Eine Vielzahl an sich unterschiedlicher Systeme ähnliche globale Eigenschaften zeigen kann, obwohl sie unterschiedliche Organisation besitzen. Der Schluss auf eine ähnlicher Organisation auf Grundlage phänomologischer Ähnlichkeiten ist daher sicher unzureichend». Ein einzelner Algorithmus, z.B. das FFW-Modell, könnte daher ein im großen und ganzen zutreffendes Abbild des Verhaltens hervorbringen, nichtsdestoweniger könnte er dabei möglicherweise nichts über das tatsächliche System aussagen, das dieses Muster hervorbringt. Ein Weg für den Modellbauer diese Kritik zu umgehen ist, daß er zunächst die von den Arbeitrinnen einer bestimmten Art tatsächlich verwendeten Algorithmen ermittelt, und diese dann in ein Modell zur Untersuchung ihrer Effekte auf das globale Muster einbaut.

Ein großer Teil der Kontroverse über das FFW-Modell kann eher auf die Behauptung genereller, universeller Gültigkeit durch ihre Autoren zurückgeführt werden, als auf das Modell selbst und seine konzeptionelle Grundlage. Beide könnten für spezifische Aufgabensituationen recht nützlich sein. Das Alter allein ist jedenfalls eine unangemessene Erklärung für die altersabhängige Arbeitsteilung, wie dies zu recht von den Verfechtern von eher altersneutralen Mechanismen behauptet wird. Ebenso klar ist die Tatsache, daß physiologische Prozesse eine bedeutende Rolle dabei spielen, welche Arbeiterinnen auf die aufgabenbezogenen Reize reagieren, und daß diese Prozesse der individuellen Flexibilität gewisse Grenzen setzen. Zum Ende könnten beide Arten von Mechanismen, altersbezogene und altersunabhängige (wie der FFWAlgorithmus) bei der Erklärung des beobachteten Musters altersabhängiger Arbeits- 
teilung eine Rolle spielen. (C) Inra/DIB/ AGIB/Elsevier, Paris

\section{Apis mellifera / Sozialverhalten / alters- abhängige Arbeitsteilung / Selbstorga- nisation / Emergente Eigenschaften}

\section{REFERENCES}

Beshers SN, Traniello JFA (1994) The adaptiveness of worker demography in the attine ant Trachymyrmex septentrionalis. Ecology 75, 763-775

Bonabeau E, Theraulaz G, Deneubourg JL, Aron S, Camazine S (1997) Self-organization in social insects. Trends Ecol Evol 12, 188-193.

Bourke AFG, Franks NR (1995) Social Evolution in Ants. Princeton Univ Press, Princeton, NJ, 529 pp

Breed MD, Robinson GE, Page RE Jr (1990) Division of labor during honey bee colony defense. Behav Ecol Sociobiol 27, 395-401

Burrell BD, Smith BH (1994) Age- but not casterelated regulation of abdominal mechanisms underlying the sting reflex of the honey bee, Apis mellifera. J Comp Physiol A, Sens, Neural, and Behav Physiol 174, 581-592

Calabi P (1988) Behavioral flexibility in Hymenoptera: a re-examination of the concept of caste. In: Advances in Myrmecology (JC Trager, ed), EJ Brill, NY

Calderone NW (1995) Temporal polyethism in the honey bee, Apis mellifera: developmental process or epiphenomenon? Can J Zool 73, $1410-1416$

Calderone NW, Page RE, Jr (1988) Genotypic variability in age polyethism and task specialization in the honey bee, Apis mellifera (Hymenoptera: Apidae). Behav Ecol Sociobiol 22, 17-25

Calderone NW, Page RE, Jr (1991) Evolutionary genetics of division of labor in colonies of the honey bee, Apis mellifera. Am Nat 138, 69.92

Calderone NW, Page RE, Jr (1992) Effects of interactions among genotypically diverse nestmates on task specialization by foraging honey bees, Apis mellifera. Behav Ecol Sociobiol 30, 219-226

Calderone NW, Page RE, Jr (1996) Temporal polyethism and behavioral canalization in the honey bee, Apis mellifera. Anim Behav 51, 631-643

Cameron SA, Robinson GE (1990) Juvenile Hormone does not affect division of labor in bumble bee colonies (Hymenoptera: Apidae). Ann Entomol Soc Am 83, 626-631

Camazine $S$ (1991) Self-organizing pattern formation on the combs of honey bee colonies. Behav Ecol Sociobiol 28, 61-76
Camazine $S$ (1993) The regulation of pollen foraging by honey bees: how foragers assess the colony's need for pollen. Behav Ecol Sociobiol $32,265-272$

Camazine S, Sneyd J, Jenkins MJ, Murray JD (1990) A mathematical model of self-organized pattern formation on the combs of honeybee colonies. $J$ Theor Biol 147, 553-571

Camazine S, Sneyd J (1991) A model of collective nectar source selection by honey bees: self-organization through simple rules. J Theor Biol 149 , 547-571

Cole BJ (1991) Short-term activity cycles in ants: generation of periodictiy by worker interactions. Am Nat 137, 244-259

Crailsheim K (1990) Protein synthesis in the honey bee (Apis mellifera $\mathrm{L}$ ) and trophallactic distribution of jelly among imagos in laboratory experiments. Zool J Physiol 94, 303-312

Crailsheim K (1991) Interadult feeding of jelly in honeybee colonies (Apis mellifera $\mathrm{L}$ ). J Comp Physiol B 161, 55-60

Crailsheim K (1992) The flow of jelly within a honeybee colony. J Comp Physiol B 162, 681-689

Deneubourg JL, Goss S (1989) Collective patterns and decision-making. Ethol Ecol Evol 1, 295-311.

Dönhoff (1855a) Über das Geruchsorgan der Biene. In: Beiträge zur Bienenkunde, Pfenningstorff, Berlin

Dönhoff (1855b) Über das Herrschen verschiedener Triebe in verschieden Lebensaltern bei den Bienen. In: Beiträge zur Bienenkunde, Pfenningstorff, Berlin

Downing HA, Jeanne RL (1988) Nest construction by the paper wasp, Polistes: a test of stigmergy theory. Anim Behav 36, 1729-1739

Fahrbach SE (1997) Regulation of age polyethism in bees and wasps by juvenile hormone. Adv Stud Behav 26, 285-316

Farrar CL (1949) The overwintering of productive colonies. In: The Hive and the Honey Bee, Dadant, Hamilton, IL

Fergusson LA, Winston ML (1988) The influence of wax deprivation on temporal polyethism in honey bee (Apis mellifera L) colonies. Can J Zool 66, 1997-2001

Fluri P (1990) How long do worker honeybees live? Schweiz Bienen-Zeitung 113, 620-625.

Fluri P (1993) On the regulation of lifespan in the honey bee. Deutsches Bienen J 1, 588-591.

Franks NR (1994) Is age polyethism a myth? In: Les Insectes Sociaux, 12th Congress of the IUSSI Paris, Sorbonne, Université Paris Nord, Paris

Franks NR, Bryant S, Griffiths R, Hemerik L (1990) Synchronization of the behavior within nests of the ant leptothorax-acervorum fabricius I. Dis- 
covering the phenomenon and its relation to the level of starvation. Bull Math Biol 52, 597-612

Franks NR, Sendova-Franks AB (1992) Brood sorting by ants distributing the workload over the work- surface. Behav Ecol Sociobiol 30, 109-123

Franks NR, Tofts C (1994) Foraging for work: how tasks allocate workers. Anim Behav 48, 470-472

Free JB (1957) The transmission of food between worker honeybees. Br J Anim Behav 5, 41-47

Free JB (1961) Hypopharyngeal gland development and division of labour in honey-bee (Apis mellifera $\mathrm{L}$ ) colonies. Proc R Entomol Soc Lond 36A, $5-8$

Free JB (1965) The allocation of duties among worker honeybees. Symp Zool Soc Lond 14, 39-59

Frumhoff PC, Baker J (1988) A genetic component to division of labor within honey bee colonies. Nature 333, 358-361

Gerstung F (1891-1926) Der Bien und Seine Zucht, 7 ed. Pfenningstorff, Berlin

Giray T, Robinson GE (1994) Effects in intracolony variability in behavioral development on plasticity of division of labor in honey bee colonies. Behav Ecol Sociobiol 35, 13-20

Gordon DM (1989a) Dynamics of task switching in harvester ants. Anim Behav 38, 194-204

Gordon DM (1989b) Caste and change in social insects. In: Oxford Surveys in Evolutionary Biology 6 (PH Harvey, L Partridge, eds), Oxford Univ Press, Oxford, pp 55-72

Gordon DM (1996) The organization of work in social insects. Nature 380, 121-124

Gordon DM, Goodwin BC, Trainor LEH (1992) A parallel distributed model of the behavior of ant colonies. J Theor Biol 156, 293-307

Guzman-Novoa E, Gary NE (1993) Genotypic variability of components of foraging behavior in honey bees (Hymenoptera: Apidae). J Econ Ento$m o l ~ 86,715-721$

Guzman-Novoa E, Page RE Jr, Gary N E (1994) Behavioral and life-history components of division of labor in honey bees (Apis mellifera L.). Behav Ecol Sociobiol 34, 409-417

Harrison $\mathbf{J}$ (1986) Caste-specific changes in honeybee flight capacity Physiol Zool 59, 175-187

Hellmich RL II, Kulincevic JM, Rothenbuhler WC (1985) Selection for high and low pollen-hoarding honey bees. $J$ Hered 76, 155-158

Hersch MI, Crewe RM, Hepburn HR, Thompson PR, Savage N (1978) Sequential development of glycolytic competence in the muscles of worker honeybees. Comp Biochem Physiol 61B. 427-431

Himmer A (1930) Von der Arbeitsteilung im Bienenstaat. Leipzig Bienenztg 45, 39-43, 64-67

Hogeweg P, Hesper B (1983) The ontogeny of the interaction structure in bumble bee colonies: a MIRROR model. Behav Ecol Sociobiol 12, 271-283
Hogeweg P, Hesper B (1985) Socioinformatic processes: MIRROR modelling methodology. $J$ Theor Biol 1 13, 31 1-330

Hölldobler B, Wilson EO (1990) The Ants. Belknap Press, Cambridge, MA

Hrassnigg N, Crailsheim K (1996) Trophallaxis of proteinaceous jelly in middle-aged honey bees. Apidologie $199627,311-313$

Huang ZY, Robinson GE (1992) Honeybee colony integration: Worker-worker interactions mediate hormonally regulated plasticity in division of labor. Proc Natl Acad Sci USA 89, 11726-11729

Huang ZY, Robinson GE (1996) Regulation of honey bee division of labor by colony age demography. Behav Ecol Sociobiol 39, 147-158

Jaycox ER (1974) Behavioral changes in worker honey bees (Apis mellifera L.) induced by injections of a juvenile hormone mimic. Ann Entomol Soc Am 67, 529-534

Jaycox ER (1976) Behavioral changes in worker honey bees (Apis mellifera L.) after injection with synthetic juvenile hormone (Hymenoptera: Apidae). J Kans Entomol Soc 49, 165-170

Jeanne RL (1986) The evolution of the organization of work in social insects. Monit Zool Ital 20 119-133

Jeanne RL (1991) Polyethism. In: The Social Biology of Wasps (KG Ross and RW Matthews, eds), Cornell Univ Press, Ithaca, NY

Kolmes SA (1985a) A quantitative study of the division of labor among worker honey bees. $Z$ Tierpsychol 68, 287-302

Kolmes SA ( 1985b) An information theory analysis of task specialization among worker honey bees performing hive duties. Anim Behav 33 $181-187$

Kolmes SA (1986) Age polyethism in worker honey bees. Ethology 71, 252-255

Kolmes SA (1989) Grooming specialists among worker honey bees, Apis mellifera. Anim Behav 37 , 1048-1049

Kolmes SA, Winston ML, Fergusson LA (1989) The division of labor among worker honey bees (Hymenoptera: Apidae): The effects of multiple patrilines. J Kans Entomol Soc 62, 80-95

Laidlaw HH (1974) Relationships of bees within a colony. Apiacta $9,49-52$

Lenoir A (1987) Factors determining polyethism in social insects. In: From Individual to Collective Behavior in Social Insects (Pasteels JM, Deneubourg J-L, eds), Birkhauser, Basel, 219-240

Lindauer M (1952) Ein Beitrag zur Frage der Arbeitsteilung im Bienenstaat. $Z$ vergl Physiol 34 , 299-345

Lindauer, M (1953) Division of labor in the honeybee colony. Bee World 34, 63-73

Lloyd JE (1983) Bioluminescence and communication in insects. Annu Rev Entomol 28, 131-160 
Masson C, Arnold, G (1984) Ontogeny, maturation and plasticity of the olfactory system in the worker bee. I Insect Physiol 30, 7-14

Maurizio A (1950) The influence of pollen feeding and brood rearing on the length of life and physiological condition of the honeybee. Preliminary report. Bee World 31, 9-12

Michener CD (1974) The Social Bees. Belknap Press, Cambridge, MA

Moore D, Angel JE, Cheeseman IM, Robinson GE, Fahrbach SE (1995) A highly specialized social grooming honey bee (Hymenoptera: Apidae). $J$ Insect Behav 8, 855 - 861

Moore AJ, Breed MD, Moor MJ (1987) The guard honey bee: ontogeny and behavioural variability of workers performing a specialized task. Anim Behav 35, 1159-1167

Morland DMT (1930) On the causes of swarming in the honey bee (Apis mellifera $\mathrm{L}$ ) An examination of the brood food theory. Ann Appl Biol $17,137-149$

Milojeciv BD (1940) A new interpretation of the social life of the honeybee. Bee World 21, 39-41

Naumann K, Winston ML (1990) Effects of swarm type on temporal caste polyethism in the honey bee, Apis Mellifera L (Hymenoptera: Apidae). Insectes Soc 37, 58-72

Nelson FC (1927) Adaptability of young bees under adverse conditions. Am Bee J 67, 242-243

Nenadovic V, Jankovic Hladni-M, Ivanovic J, Stanic $\mathrm{V}$ (1985) Cytological changes in corpora allata of newly emerged adult worker bees Apis mellifera L (Hym, Apidae). Acta Entomol Jugoslarica 21, 79-85

Nicolis G, Prigogine I (1977) Self-organization in Non-equilibrium Systems. Wiley

Nixon HL, Ribbands CR (1952) Food transmission within the honeybee community. Proc $R S o c$ Lond Ser B 140, 43-50

Nolan WJ (1924) The division of labor in the honeybee. NC Beekeeper (Oct), 10-15

O'Donnell S, Jeanne RL (1993) Methoprene accelerates age polyethism in workers of a social wasp (Polybia occidentalis). Physiol Entomol $18,189-194$

O'Donnell S, Jeanne RL (1995) Implications of senescence patterns for the evolution of age polyethism in eusocial insects. Behav Ecol 6, 269-273

Omholt SW (1988) Relationships between worker longevity and the intracolonial population dynamics of the honeybee. $J$ Theor Biol 130, 275-284

Oster GF, Wilson EO (1978) Caste and Ecology in the Social Insects. Princeton Univ Press, Princeton, NY

Pacala SW, Gordon D, Godfray HCJ (1996) Effects of social group size on information transfer and task allocation. Evol Ecol 10, 127-165
Page RE, Jr, Robinson GE (1991) The genetics of division of labour in honey bee colonies. $A d v$ Insect Physiol 23, 117-169

Page RE, Jr, Robinson GE, Britton DS, Fondrk MK (1992) Genotypic variability for rates of behavioral development in worker honeybees (Apis mellifera L ). Behav Ecol 3, 173-180

Page RE, Jr, Mitchell SD (1998) Self organization and division of labor in insect societies. Apidologie 29, 171-190

Pham-Delègue $\mathrm{MH}$, Trouiller J, Bakchine E, Roger B, Masson C (1991) Age dependency of worker bee response to queen pheromone in a fourarmed olfactometer. Insectes $S o c \cdot 38,283-292$

Pham-Delègue MH, Trouiller J, Caillaud CM, Roger B, Masson C (1993) Effect of queen pheromone on worker bees of different ages: Behavioural and electrophysiological responses. Apidologie 24, 267-281

Porter SD, Jorgensen CD (1981) Foragers of the harvester ant, Pogonomyrmex owyhee $i$ a disposable caste? Behav Ecol Sociobiol 9, 247-256

Ribbands CR (1952) Division of labour in the honeybee community. Proc $R$ Soc Lond B 142, 515-524

Robinson GE (1985) Effects of a juvenile hormone analogue on honey bee foraging behvaiour and alarm pheromone production. J Insect Physiol 31, 277-282

Robinson GE (1987a) Regulation of honey bee age polyethism by juvenile hormone. Behav Ecol Sociobiol 20, 329-338

Robinson GE (1987b) Modulation of alarm pheromone perception in the honey bee: evidence for division of labor based on hormonally regulated response thresholds. I Comp Physiol A 160 , 613-619

Robinson GE (1992) Regulation of division of labor in insect societies. Annu Rev Entomol 37, 637-665

Robinson G E, Underwood BA, Henderson CEA (1984) A highly specialized water-collecting honey bee. Apidologie 15, 355-358

Robinson GE, Page RE, Jr, Strambi C, Strambi A (1992) Colony integration in honey bees: Mechanisms of behavioral reversion. Ethology 90 , 336-348

Robinson GE, Page RE, Huang ZY (1994) Temporal polyethism in social insects is a developmental process. Anim Behav 47, 1-3

Robinson GE, Page RE, Jr (1995) Genotypic constraints on plasticity for corpse removal in honey bee colonies. Anim Behav 49, 867-876

Robinson GE, Vargo EL (1997) Juvenile hormone in adult eusocial Hymenoptera: Gonadotropin and behavioral pacemaker. Arch Insect Biochem Physiol 35, 559-583

Robinson GE, Huang ZY (1998) Colony integration in honey bees: genetic, endocrine, and social 
control of division of labor. Apidologie 29 , $159-170$

Robson SK, Beshers SN (1997) Division of labour and 'foraging for work': simulating reality versus reality of simulations. Anim Behav 53, 214-218

Rosengaus RB, Traniello JFA (1993) Temporal polyethism in incipient colonies of the primitive termite Zootermopsis angusticollis: A single multiage caste. J Insect Behav 6, 237-252

Rösch GA (1925) Untersuchungen über die Arbeitsteilung im Bienenstaat, I Teil: die Tätigkeiten im normalen Bienstaate und ihre Beziehungen zum Alter der Arbeitsbienen. Z Vergl Physiol 2, 571631

Rösch GA (1927) Über die Bautätigkeit im Bienenvolk und das Alter der Baubienen Weiterer Beitrag zur Frage nach der Arbeitsteilung im Bienenstaat. Z Vergl Physiol 6, 265-298

Rösch GA (1930) Untersuchungen über die Arbeitsteilung im Bienenstaat, II Teil: die Tätigkeiten der Arbeitsbienen unter experimentell veränderten Bedingungen. Z Vergl Physiol 12, 1-71

Rösch GA (1931) Neue Beobachtungen und Versuche über die Arbeitsteilung im Bienenstaat. Forsch Fortschr Dtsch Wiss 7, 86

Ross KG, Matthews RW (eds) (1991) The Social Biology of the Wasps. Cornell Univ Press, Ithaca, NY

Sakagami SF, Fukuda H (1968) Life tables for worker honeybees. Res Pop Ecol 10, 127-139

Schmid-Hempel P (1992) Worker castes and adaptive demography. J Evol Biol 5, 1-12

Schmid-Hempel P, Schmid-Hempel R (1984) Life duration and turnover of foragers in the ant Cataglyphis bicolor (Hymenoptera: Formicidae). Insectes Soc 31, 345-360

Seeley TD (1982) Adaptive significance of the age polyethism schedule in honeybee colonies. Behav Ecol Sociobiol 11, 287-293

Seeley TD (1985) Honeybee Ecology. Princeton Univ Press, NJ

Seeley TD (1989) Social foraging in honey bees: how nectar foragers assess their colony's nutritional status. Behav Ecol Sociobiol 24, 181-199

Seeley TD (1995) The Wisdom of the Hive. Harvard Univ Press, Cambridge, MA

Seeley TD, Morse RA (1976) The nest of the honey bee (Apis mellifera $\mathrm{L}$ ). Insectes Soc 23, 495-512

Seeley TD, Camazine S, Sneyd J (1991) Collective decision-making in honey bees: how colonies choose among nectar sources. Behav Ecol Sociobiol 28, 277-290

Seeley TD, Kolmes SA (1991) Age polyethism for hive duties in honey bees - illusion or reality. Ethology 87, 284-297

Seeley TD, Kuhnholtz S, Weidenmuller A (1996) The honey bee's tremble dance stimulates additional bees to function as nectar receivers. Behav Ecol Sociobiol 39, 419-427
Sekiguchi K, Sakagami SF (1966) Structure of foraging populations and related problems in the honeybee, with consideration s on the division of labour in bee colonies. Hokkaido Natl Agric Exp Sta Rep 69, 1-65

Sendova-Franks A, Franks NR (1993) Task allocation in ant colonies within variable environments (a study of temporal polyethism: experimental). Bull Math Biol 55, 75-96

Sorensen AA, Busch TM, Vinson SB (1985) Trophallaxis by temporal subcastes in the fire ant, Solenopsis invicta, in response to honey. Physiol Entomol 10, 105-111

Skarka V, Deneugourg JL, Belic MR (1990) Mathematical model of building behavior of Apis mellifera. J Theor Biol 147, 1-16

Stuart RJ (1997) Division of labor in social insect colonies: self-organization and recent revelations regarding age, size and genetic differences. In: Comparative Psychology of Invertebrates: the Field and Laboratory Study of Insect Behavior (G Greenberg, E Tobach, eds), Garland Press, NY

Szolderits MJ, Crailsheim K (1993) A comparison of pollen consumption and digestion in honeybee (Apis mellifera carnica) drones and workers. $J$ Insect Physiol 39, 877-881

Theraulaz G, Bonabeau E, Deneubourg J-L (1995) Self-organization of hierarchies in animal societies: the case of the primitively eusocial wasp Polistes dominulus Christ. J Theor Biol 174, 313-323

Tofts C (1993) Algorithms for task allocation in ants (A study of temporal polyethism: Theory). Bull Math Biol 55, 891-918

Tofts C, Franks NR (1992) Doing the right thing: Ants, honeybees and naked mole-rats. Trends Ecol Evol 7, 346-349

Trainello JFA (1978) Caste in a primitive ant: absence of age polyethism in Amblyopone. Science 202, 770-772

Trainello JFA, Rosengaus R (1997) Ecology, evolution and division of labour in social insects. Anim Behav 53, 209-213

Van der Blom J (1992) Individual involvement in queen-attending of worker honeybees. Insectes Soc 39, 237-249

Van der Blom J (1993) Individual differentiation in behaviour of honey bee workers (Apis mellifera L). Insectes Soc 40, 345-361

Visscher PK (1983) The honey bee way of death: necrophoric behaviour in Apis mellifera colonies. Anim Behav 31, 1070-1076

Visscher PK, Dukas R (1997) Survivorship of foraging honey bees. Insectes Soc 44, 1-5

Watmough J, Camazine S (1995) Self-organized thermoregulation of honeybee clusters. $J$ Theor Biol 176, 391-402

West-Eberhard MJ (1981) Intragroup selection and the evolution of insect societies In: Natural Selec- 
tion and Social Behavior (Alexander R, Tinkle DW, eds), Chiron Press, NY

Wilson EO (1971) The Insect Societies. Belknap Press of the Harvard Univ Press, Cambridge, MA

Wilson EO (1976) Behavioral discretization and the number of castes in an ant species. Behav Ecol Sociobiol 1, 141-154

Wilson EO (1978) Division of labor in fire ants based on physical castes (Hymenoptera: Formicidae: Solenopsis). J Kans Entomol Soc 51, 615-636

Wilson EO (1980a) Caste and division of labor in leaf-cutter ants (Hymenoptera: Formicidae: Atta) I. The overall pattern in A. sexdens. Behav Ecol Sociobiol 7, 143-156

Wilson EO (1980b) Caste and division of labor in leaf-cutter ants (Hymenoptera: Formicidae: Atta) II. The ergonomic optimization of leaf-cutting. Behav Ecol Sociobiol 7, 157-165

Wilson EO (1985) The sociogenesis of insect colonies. Science 228, 1489-1496
Wilson EO (1987) Causes of ecological success: The case of the ants. J Anim Ecol 56, 1-9

Wilson EO, Eisner T (1957) Qualitative studies of liquid food transmission in ants. Insectes Soc 4 , $11-166$

Winston ML (1987) The Biology of the Honey Bee. Harvard Univ Press, Cambridge, MA

Winston ML, Katz SJ (1982) Longevity of crossfostered honey bee workers (Apis mellifera) of European and Africanized races. Behav Ecol Sociobiol 10, 125-129

Winston ML, Punnett EN (1982) Factors determining temporal division of labor in honeybees. Can J Zool 60, 2947-2952

Winston ML, Fergusson LA (1985) The effect of worker loss on temporal caste structure in colonies of the honey bee (Apis mellifera L). Can J Zool 63, 777-780

Winston ML, Fergusson LA (1986) Influence of the amount of eggs and larvae in honeybee colonies on temporal division of labour. J Apic Res 25 , $238-241$ 